\title{
Vitamin D and COVID-19: An Overview of Recent Evidence
}

\author{
Drishti Ghelani, Simon Alesi and Aya Mousa *(D)
}

Citation: Ghelani, D.; Alesi, S.;

Mousa, A. Vitamin D and COVID-19: An Overview of Recent Evidence. Int. J. Mol. Sci. 2021, 22, 10559. https:// doi.org/10.3390/ijms221910559

Academic Editors: Andrzej Slominski and Frank De Gruijl

Received: 6 August 2021

Accepted: 23 September 2021

Published: 29 September 2021

Publisher's Note: MDPI stays neutral with regard to jurisdictional claims in published maps and institutional affiliations.

Copyright: (c) 2021 by the authors. Licensee MDPI, Basel, Switzerland. This article is an open access article distributed under the terms and conditions of the Creative Commons Attribution (CC BY) license (https:/ / creativecommons.org/licenses/by/ $4.0 /)$.
Monash Centre for Health Research and Implementation (MCHRI), Public Health and Preventive Medicine, Faculty of Medicine, Nursing and Health Sciences, Monash University, Melbourne, VIC 3168, Australia; drishti.ghelani@monash.edu (D.G.); simon.alesi@monash.edu (S.A.)

* Correspondence: aya.mousa@monash.edu

\begin{abstract}
The novel coronavirus severe acute respiratory syndrome ( $S A R S-C o V-2)$ has progressed rapidly from an outbreak to a global pandemic, with new variants rapidly emerging. Coronavirus disease 2019 (COVID-19), the disease resulting from SARS-CoV-2 infection, can lead to multiorgan damage. Due to the extremely contagious and fatal nature of the virus, it has been a priority of medical research to find effective means of treatment. Amid this search, the role of vitamin $\mathrm{D}$ in modulating various aspects of the innate and adaptive immune system has been discussed. This review aims to consolidate the research surrounding the role of vitamin $\mathrm{D}$ in the treatment and prevention of COVID-19. While there are some conflicting results reported, the consensus is that vitamin $\mathrm{D}$ has a host of immunomodulatory effects which may be beneficial in the context of COVID-19 and that low levels of vitamin D can result in dysfunction of crucial antimicrobial effects, potentially contributing to poor prognosis. Studies also show that the effects of low vitamin D can be mitigated via supplementation, although the benefits of vitamin D supplementation in the treatment of COVID-19 remain controversial.
\end{abstract}

Keywords: vitamin D; coronavirus; COVID-19; SARS-CoV-2; immunity; infection; review

\section{Introduction}

The coronavirus severe acute respiratory syndrome outbreak of 2019, subsequently named SARS-CoV-2, was first reported in Wuhan, China [1]. This coronavirus, initially mimicking symptoms from previous outbreaks such as the Middle Eastern respiratory syndrome (MERS-CoV) and SARS-CoV, is a droplet-borne respiratory virus [2]. Patients infected with SARS-CoV often present with fevers, and lower respiratory tract illness [3]. This state of $S A R S-C o V-2$ infection and the resulting disease is known as coronavirus disease 2019, commonly referred to as COVID-19. The onset of symptoms can be sudden and severe and may be accompanied by a dry cough and other flu-like symptoms such as body aches and headaches. The cough sometimes progresses to pneumonia, which can be fatal despite receiving the best care that modern medicine can provide [4].

As of July 2021, SARS-CoV-2 had infected more than 187 million people, resulting in over four million deaths [5]. Of those who recovered after hospital admission, approximately 60\% are believed to have 'long COVID' [6]. 'Long COVID' refers to a condition whereby COVID-19 symptoms persist beyond 3-4 weeks after the initial infection $[7,8]$. These symptoms include pulmonary, cardiovascular, haematological, neuropsychiatric, renal, endocrine, gastrointestinal, hepatobiliary, and inflammatory sequelae [9]. In a span of less than two years, strategies for dealing with the outbreak and global spread of the virus have transitioned from containment to attempted management to prevention by means of vaccination.

Vitamin D is a well-documented modulator of immune responses. Due to the immense toll of COVID-19 on the immune system, there has been significant interest in the potential of vitamin $\mathrm{D}$ to ameliorate or prevent detrimental immune responses. A number of new studies have been published, warranting narrative synthesis to summarise the state of 
knowledge in this field. This review thus aims to consolidate the evidence surrounding vitamin D in relation to COVID-19, with the intention of gauging the current consensus regarding vitamin D supplementation as a means to treat and/or prevent COVID-19 onset or progression. We provide an overview of the state of knowledge in this area, with reference to key studies and systematic reviews that have been published to date.

\section{Virology of SARS-CoV-2}

In terms of virology, SARS-CoV-2 is an enveloped, positive sense, single-stranded ribonucleic acid (RNA) virus [10]. The virus is able to spread easily and can mutate to form new strains which are often more virulent and more contagious [11]. The $\alpha$ (alpha) variant isolated in the UK was found to be $75 \%$ more transmissible [12] and $61 \%$ more fatal [13] compared to the original outbreak, while the $\Delta$ (delta) strain isolated in India was found to be even more contagious. The spike protein on the envelope of coronaviruses is responsible for the crown-like appearance of the virion [14]. TMPRSS2, a serine protease found on the host cell primes the spike protein, which then binds to the angiotensin-converting enzyme 2 (ACE2) "receptors" [15]. ACE2 physiologically inactivates angiotensin II and serves as a negative regulator of the renin-angiotensin-aldosterone (RAAS) system [16]. ACE2 is not a receptor in the classical sense where ligands bind and result in a downstream intracellular response. It is an enzyme found on the surface of many different cell types. However, SARS$\mathrm{CoV}-2$ uses it as a receptor to mediate entry into epithelial cells. Not surprisingly, this can be quite deleterious to cardiovascular health. Investigations after the 2004 SARS-CoV outbreak revealed that mutations within the receptor binding domain of the spike protein were the key factor in determining how contagious a particular strain was [17]. As compared to the 2004 outbreak, SARS-CoV-2 is much more contagious [18]. This is attributed to changes in the chemistry of the binding site, which result in easier cleavage of specific viral envelope proteins, allowing easier entry into host cells [17]. Furthermore, post-translational addition of glycans to flank this cleavage site have been speculated to protect it from host immune responses [19]. Virus particles are only able to enter ACE2 expressing cells [20]. In the respiratory tract, $S A R S-C o V-2$ particles enter directly via type 2 alveoli cells, which are physiologically responsible for the production of surfactant. Binding to ACE2 triggers endocytosis, followed by membrane fusion, allowing the uncoated (+)ssRNA to enter the cytoplasm [21]. Once in the cell, the positive sense RNA of the virus uses the host cell translation machinery and resources to produce proteins required for the production of more virions [22]. These host cells are thus unable to fulfil their physiological function, resulting in a reduction in surfactant production and a subsequent reduction in oxygen saturation, increased rate of respiration, and ultimately, respiratory failure [23].

\section{Pathogenesis/Pathophysiology}

A study in mouse models of SARS-CoV infections showed that ACE2 was not only crucial as a receptor for viral entry, but also resulted in decreased expression of ACE2, which was directly linked to severe lung failure and adult respiratory distress syndrome (ARDS) [24,25]. Mechanistically, ACE2 downregulation or knockouts have been linked to increased elastase activity (indicating increased stiffness of the lung), decreased blood oxygenation, and thus pulmonary oedema [26]. In addition, aspiration of gastric fluids can also lead to lung injury or symptoms of ARDS [27].

In a phenomenon called a 'cytokine storm', an overly active immune system has been known to disrupt the delicate balance between clearing the infection and an auto-immune condition. These cytokine storms have been referred to in the context of graft-versus-host disease in transplantations [28], as well as in the H5N1 avian influenza virus infection [29]. Acute lung injury, which results from infection or insult to the lungs, causes resident lung cells to release chemoattractants, which recruit circulating neutrophils to infiltrate the epithelium and airspaces [30]. Infiltration increases the permeability of the epithelial and endothelial surfaces by means of toxic proteases, peptides and oxidants. This results in apoptosis of endothelial and epithelial cells [31]. However, even in the absence of apoptosis, 
the inflammatory effects of neutrophils within the epithelium are a significant component of lung injury [31]. This inflammation reduces fluid exchange and surfactant production, leading to oedema [32].

The initial infection induces various protective inflammatory responses in the host, including an increase in the expression of pro-inflammatory cytokines such as interferon (IFN)- $\gamma$, interleukin (IL)-1, IL-6 and IL-12, as well as in chemokines such as C-C motif chemokine ligands (CCL) including CCL-2 (also known as monocyte chemoattractant protein-1) and CCL-5 (also known as RANTES), as well as C-X-C motif chemokine ligands $(\mathrm{CXCL}$ ) including CXCL2 (also known as macrophage inflammatory protein-2 $\alpha$ ) and CXCL8 (also known as IL-8) [33,34]. An increase in cytokine production leads to increased recruitment of immune cells to the area and thus greater compromise to the structural integrity of the vasculature and epithelia [31]. These cytokines and chemokines cause $\mathrm{T}$ cells to favour a Th1 phenotype to mount a full pro-inflammatory response. The delayed, excessive production of these cytokines is pathological. Clinically, it was observed that SARS patients in the intensive care unit (ICU) had markedly higher levels of these markers, as well as tumour necrosis factor (TNF $\alpha)$, a pyrogenic pro-inflammatory mediator that is associated with infection and autoimmune disorders. In addition, there were reduced levels of the anti-inflammatory marker, IL-10 [35]. Histology of patients who died from previous coronaviruses such as $S A R S-C o V$ showed increased neutrophils and macrophages in lung infiltrates, in addition to increased neutrophils and monocytes and reduced CD4 ${ }^{+}$ and $\mathrm{CD} 8^{+}$cell counts in the periphery $[36,37]$. As a result of the Th- 1 shift and excessive inflammation in COVID-19 patients, ARDS often leads to cardiopulmonary disorders, multiple organ failure, and eventually death [38].

\section{Vitamin D and the Immune System}

Vitamin D has been classically linked to calcium absorption and bone health. However, over the last decade, the key role of vitamin D in inflammation and immunoregulation has been increasingly recognised. Despite this critical role, the prevalence of vitamin D deficiency remains widespread, with 25-hydroxyvitamin D (25(OH)D) levels below $50 \mathrm{nmol} / \mathrm{L}$ (the common threshold for defining vitamin D deficiency [39]) affecting approximately $25 \%$ of US and Australian populations, as well as nearly $40 \%$ of Canadian and European populations [40,41]. These deficiency rates are largely attributed to the rising prevalence of obesity and sedentary indoor lifestyles, as well as sunscreen use and sun avoidance from fears of skin cancer.

Vitamin D can be derived from supplements in the form of vitamin $\mathrm{D}_{2}$ (ergocalciferol) or $\mathrm{D}_{3}$ (cholecalciferol) with limited amounts available via dietary sources including oily fish, egg yolk and fortified dairy [42]. Nevertheless, sun exposure remains the main source of vitamin D, whereby skin exposure to ultraviolet B (UVB) radiation results in the proteolytic cleavage of 7-dihydrocholesterol for conversion into pre-vitamin $\mathrm{D}_{3}$ [43]. Pre-vitamin $\mathrm{D}_{3}$ is stabilised by spontaneous isomerisation and ejected from the cell in the dermis/epidermis before being transported systemically [43]. This compound, however, is biologically inert and undergoes a series of hydroxylations, first by 25-hydroxylase (CYP2R1) in the liver, then by $1 \alpha, 25$-hydroxylase (CYP27B1) in the kidney, to form the immunologically active form of vitamin $\mathrm{D}, 1 \alpha, 25$-dihydroxyvitamin $\mathrm{D}\left(1,25(\mathrm{OH})_{2} \mathrm{D}_{3}\right.$ or calcitriol) $[44,45]$. Calcitriol has several functions that regulate the response of both the innate and adaptive immune systems. For instance, calcitriol modulates cytokine and chemokine expression and decreases IL-12 production in dendritic cells as well as IL-2 and IFN $\gamma$ production by $\mathrm{CD}^{+} \mathrm{T}$ cells [46].

Vitamin D exerts its effects by binding to a nuclear vitamin D receptor (VDR), which is expressed in various immune cells, with particularly high levels in dendritic cells (antigenpresenting cells), macrophages, and $\mathrm{T}$ (e.g., $\mathrm{CD}^{+}$and $\mathrm{CD} 8^{+}$) and B lymphocytes [47,48]. As a steroid hormone, vitamin $\mathrm{D}$ is able to cross lipid membranes, and interact directly with its nuclear receptor. This binding action leads to transcriptional regulation of target genes, including those coding for inflammatory mediators and proteins required to alter 
phenotypes of immune cells [49]. However, the immunomodulatory effects of vitamin D signalling are determined by phenotypes of the target immune cells. For example, naïve $\mathrm{T}$ cells express VDRs in basal concentrations, but this is increased dramatically upon activation [50,51]. In monocytes, however, differentiated monocytes (macrophages/dendritic cells) express fewer VDRs [52]. Vitamin D is also involved in several signalling pathways that are activated in a non-genomic manner by calcitriol [53].

Vitamin D has also been said to affect protein synthesis, where it interacts with proteins other than the VDR that are involved in the folding of newly synthesised glycoproteins [54]. It has also been postulated that supplementation of vitamin $\mathrm{D}$ alters pathways involved in histone and chromatin modifications in a manner distinct from VDR activity [55]. In a novel biosynthetic pathway mediated by CYP11A1, vitamin D is also activated by hydroxylation at different sites, resulting in the formation of different non-calcaemic hydroxyderivatives that act with different potency on the VDR [56]. The site of hydroxylation determines the action of the derivative, in that they may act as partial or selective agonists of the VDR, but as full agonists of alternative nuclear receptors [57]. These CYP11A1-derived hydroxyderivatives, in addition to classical calcitriol, exert important anti-inflammatory and anti-oxidative effects involving downregulation of nuclear factor kappa-B (NF-kB) and inverse agonism on retinoic acid-related orphan receptors ( $\mathrm{ROR} \gamma$ ) resulting in diminished Th17 responses. Anti-oxidative and reparative responses have also been demonstrated, involving activation of nuclear factor erythroid 2p45-related factor 2 and p53 [58]. Importantly, vitamin D delivered orally is not recognized by CYP11A1. Hence, parenteral delivery of vitamin $\mathrm{D}$ would be required to bypass the liver and produce CYP11A1-derived hydroxyderivatives, with corresponding anti-oxidative and cytokine storm-suppressing effects, potentially mitigating multi-organ damage and death from COVID-19 [58].

\subsection{Vitamin D in Innate Immunity}

One aspect of innate immunity influenced by calcitriol is the enhancement of phagocytotic activity of macrophages. Macrophages and monocytes use Toll-like receptors (TLRs) to sense pathogen-associated molecular patterns (PAMPs) on infectious agents, and in turn, phagocytose these agents in what is known as the first line of defence. Calcitriol has been shown to enhance the antimicrobial capabilities of these innate immune cells.

Immune signalling such as those of IFN $\gamma$, STAT- $1 \alpha$, lipopolysaccharide (LPS) and TLRs increases expression of $1 \alpha$ hydroxylase in monocytes. $1 \alpha$ hydroxylase catalyses the formation of $1,25(\mathrm{OH})_{2} \mathrm{D}_{3}$, which has been shown to stimulate monocyte differentiation, with cells looking phenotypically like macrophages following $1,25(\mathrm{OH})_{2} \mathrm{D}_{3}$ exposure [59]. In macrophages, stimulation with $1,25(\mathrm{OH})_{2} \mathrm{D}_{3}$ has an anti-inflammatory effect by increasing IL-10 production and decreasing pro-inflammatory markers such as TNF $\alpha$, IL- $1 \beta$, IL-6, and cyclooxygenase-2 (COX-2), by means of the mitogen-activated protein kinase (MAPK) phosphatase pathway $[60,61]$.

In addition, while TLR activation results in increased expression of the VDR, $1,25(\mathrm{OH})_{2} \mathrm{D}_{3}$ is able to downregulate the expression of miRNA155, which when expressed, reduces anti-inflammatory gene expression $[62,63]$. Studies have also shown that the ligand-bound VDR is able to modulate the epigenome of immune cells, monocytes in particular [64].

In dendritic cells, $1,25(\mathrm{OH})_{2} \mathrm{D}_{3}$ binding triggers a shift to a more tolerogenic phenotype, both in cell morphology and expression of surface proteins $[65,66]$. There is a marked decrease in major histocompatibility complex (MHC) class II receptors as well as CD80 and CD86 co-stimulatory molecules needed to mount an immune response [66]. Simultaneously, there is an increase in CCR-5 and CD40 receptors, favouring an anti-inflammatory environment [67]. Additionally, $1,25(\mathrm{OH})_{2} \mathrm{D}_{3}$ increases expression of programmed death-ligand 1 (PD-L1) and TNF, which induces the activity of regulatory T cells-a net anti-inflammatory effect $[68,69]$.

VDRs are also expressed in natural killer (NK) cells and neutrophils [70]. VDR signalling has been shown to enhance neutrophil killing of naïve cells while decreasing the amount of pro-inflammatory cytokines produced by infected neutrophils [71]. Essen- 
tially, $1,25(\mathrm{OH})_{2} \mathrm{D}_{3}$ optimises neutrophil response while preventing excessive response. $1,25(\mathrm{OH})_{2} \mathrm{D}_{3}$ has also been shown to modulate NK cell response by decreasing expression of IFN $\gamma$ and reducing cytotoxic activity [72,73].

\subsection{Vitamin D in Adaptive Immunity}

The anti-inflammatory effect of $1,25(\mathrm{OH})_{2} \mathrm{D}_{3}$ signalling on dendritic cells and macrophages (i.e., downregulation of MHC II and co-stimulatory molecules, reduced pro-inflammatory signalling) modulates the response of $\mathrm{T}$ lymphocytes. This decreases proliferation of autoreactive T cells, which have the potential for autoimmune activity, and in some cases, increases proliferation of regulatory T cells (Tregs) [74,75]. Anti-inflammatory cytokines also induce a Th2 phenotype as opposed to Th1 or Th17 [76].

Directly, however, $1,25(\mathrm{OH})_{2} \mathrm{D}_{3}$ signalling in T cells is varied depending on the phenotype and state of differentiation. Upon activation, $\mathrm{T}$ lymphocytes express higher levels of VDR [77]. Stimulation with $1,25(\mathrm{OH})_{2} \mathrm{D}_{3}$ reduces signalling of IL-2 and IFN $\gamma(\mathrm{Th} 1)$ and IL-17 and IL-21 (Th17) cytokines [76,78], while acting synergistically with IL-2 to induce and perpetuate a Th2 phenotype [78].

VDR expression in $B$ cells has been shown to induce apoptosis in activated B cells. In addition, $1,25(\mathrm{OH})_{2} \mathrm{D}_{3}$ signalling reduces generation of plasma cells and $\mathrm{B}$ cells that have undergone antibody class switching, without affecting B cell differentiation itself $[79,80]$. It has since been speculated that calcitriol has potentially beneficial effects in the context of the role of $B$ cells in autoimmune diseases [70]. Calcitriol also increases anti-inflammatory IL-10 production in $\mathrm{B}$ cells and reduces $\mathrm{T}$ cell activation by $\mathrm{B}$ cells by altering the composition of cell surface markers [81].

More recently, there has been evidence showing that vitamin $\mathrm{D}$ and its hydroxyderivatives are able to bind and activate the liver $X$ receptor (LXR) [82]. The LXR has been independently linked to regulating the switch in $\mathrm{T}$ cell phenotypes and thus the function of the adaptive immune system [83].

\section{Vitamin D and COVID-19: Summary of the Evidence}

\subsection{Overview}

The putative role of vitamin D in the treatment or management of COVID-19 is complex and dynamic. As described above, vitamin $\mathrm{D}$ is capable of modulating different aspects of immunity, with potential to influence COVID-19 severity and outcomes. SARS-CoV-2 infections lead to downregulation of ACE2, causing toxic accumulation of Ang II, which in turn contributes to ARDS. Vitamin D has been found to attenuate the effects of these interactions between SARS-CoV-2 and the RAAS [84]. As a negative endocrine regulator on the RAAS, vitamin D is able to induce the vasorelaxant ACE2/Ang-(1-7)/Mas receptor axis, which protects against acute lung injury and ARDS (Figure 1) [85]. Vitamin D is a negative regulator of renin biosynthesis and works by binding to the VDR and preventing expression of renin-producing enzymes and proteins [86]. Vitamin D has also been shown to increase the expression of ACE2 [86]. There has been evidence suggesting that a potential cause for the differential presentation of COVID-19 between males and females (higher odds of ICU admissions and death in males) is due to different expressions of ACE2, which results in a heightened and more effective immune response in females [87-89]. The influence of ACE2 expression on COVID-19 severity is determined at this stage, where it has been established that ACE2 is expressed in greater concentrations in males than females $[90,91]$. A study using an animal model found that females post oophorectomy showed increased ACE2 activity compared to before, showing that many of these differences can be attributed to the presence of oestrogen [92]. Essentially, males having increased ACE2 expression and not having the cardioprotective effect of oestrogen results in increased severity of COVID19. While complex mechanisms for the cardiovascular sequelae of COVID-19 have been proposed [93], that the damage occurs is undeniable [94]. COVID-19 causes the burden on the cardiovascular system to be dramatically increased, a process in which ACE2 and the RAAS have been implicated [93], and those with pre-existing cardiovascular morbidities 
are at greater risk of complications and mortality [94]. A case analysis of 43 patients in China found that males were more likely to have more severe COVID-19 as opposed to females [95]. Similar differences were observed in the US and Europe [96-98].

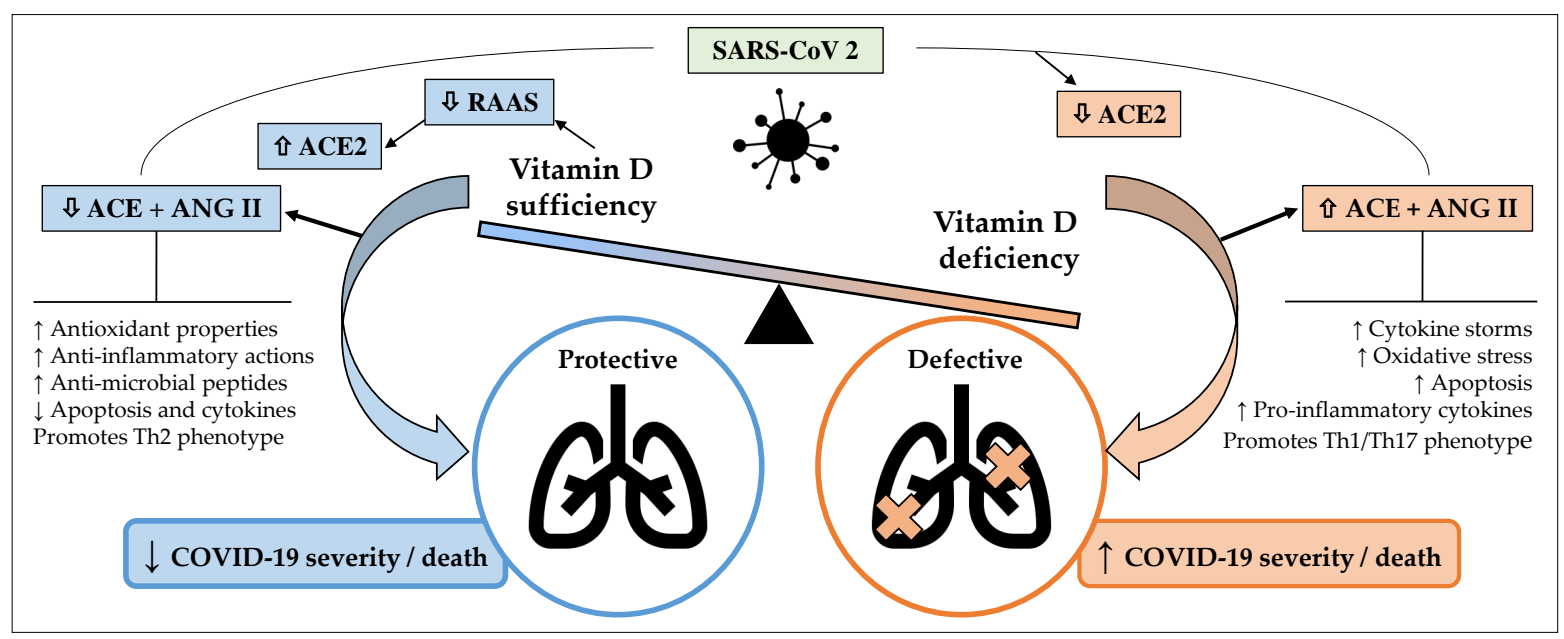

Figure 1. Potential mechanisms by which sufficient serum vitamin D levels may confer protective effects against coronavirus disease 2019 (COVID-19) and acute lung injury, whereas vitamin D deficiency may contribute to a defective immune response against COVID-19 and increased severity and/or mortality. ACE, angiotensin-converting enzyme; ANG, angiotensin; COVID-19, coronavirus disease 2019; RAAS, renin angiotensin aldosterone system; SARS-CoV-2, severe acute respiratory syndrome coronavirus 2 . Arrows pointing up indicate an increase; arrows pointing down indicate a decrease.

Other observational studies suggested that different levels of $1,25(\mathrm{OH})_{2} \mathrm{D}_{3}$ and VDR expression may be implicated in the differences between males and females [99,100]. Beyond the mechanistic explanation of $1,25(\mathrm{OH})_{2} \mathrm{D}_{3}$ signalling altering the immune response, females have the added benefit of vitamin D working synergistically with oestrogen, exerting a protective effect in CD4+ T cells to prevent an autoimmune response [101]. However, describing gender differences in COVID-19 as a result of ACE2 or vitamin D may be simplistic. In a manner that could be highly variable due to individual differences, this could be attributed to fewer morbidities, as oestrogen confers a protective effect in cardiovascular and immunological health [102].

Local activation from $25(\mathrm{OH}) \mathrm{D}_{3}$ to the active $1,25(\mathrm{OH})_{2} \mathrm{D}_{3}$ is of considerable importance in the context of an antiviral response in the respiratory system. VDRs are constitutively expressed, and $1 \alpha$ hydroxylase is present in high levels in macrophages and epithelia, among other cell types [103-106]. Stimulation of $1,25(\mathrm{OH})_{2} \mathrm{D}_{3}$ in lung epithelia has been shown to induce expression of antimicrobial peptides such as cathelicidin 1 and defensin $\beta 4$, in addition to the production of cathelicidin 1 in large amounts by macrophages, and lower amounts in dendritic cells $[63,107] .1,25(\mathrm{OH})_{2} \mathrm{D}_{3}$ and VDR signalling play a similarly significant role in the lung epithelia, and their roles in modulating responses to influenza and respiratory syncytial virus have been characterised [108,109]. It is possible that insufficient vitamin D levels contribute to cytokine storms, inadequate protection from epithelial cell apoptosis, and deficient epithelial cell repair, ultimately making the lungs vulnerable to fatal immune system dysregulation. The evidence that vitamin $\mathrm{D}$ is a better and more holistic modulator of the immune system than antibody therapy to prevent the action of cytokines like IL-6 is not surprising [110].

It was found that vitamin $\mathrm{D}$ and its biologically active hydroxyderivatives are likely to inhibit the action of the TMPRSS2 [111]. This results in blocking of the fusion between the viral spike protein and ACE2, which is required for viral entry into the host cell. The biologically active molecules that prevent this interaction with the serine protease have varying synthetic pathways and carry out different biological functions. Based on computational investigations, $1 \alpha, 25(\mathrm{OH})_{2} \mathrm{D}_{3}, 25(\mathrm{OH}) \mathrm{D}_{3}, 1 \alpha, 20 \mathrm{~S}(\mathrm{OH})_{2} \mathrm{D}_{3}, 20 \mathrm{~S}, 23 \mathrm{R}(\mathrm{OH})_{2} \mathrm{D}_{3}$, $20 \mathrm{~S}, 23 \mathrm{~S}(\mathrm{OH})_{2} \mathrm{D}_{3}$ and $1 \alpha, 20 \mathrm{~S}, 23 \mathrm{~S}(\mathrm{OH})_{3} \mathrm{D}_{3}$ are promising inhibitors of TMPRSS2 [111]. There 
has been evidence of vitamin $\mathrm{D}$ attenuating damage from pro-inflammatory mediators such as NF- $\mathrm{kB}$ and IL-17 in the skin after exposure to UVB [57]. If replicated in the systemic circulation, this mechanism is highly likely to ameliorate the effects of cytokine storms [112]. As mentioned earlier, however, the route of delivery of vitamin D is a key factor that should be considered since this has a profound impact on circulating derivatives of vitamin D [58].

In addition, a study investigating the targets of $S A R S-\mathrm{CoV}-2$ using genomics guided tracing has also confirmed the role of vitamin D in COVID-19. Glinsky [113] explored vitamin $\mathrm{D}$ as a putative repressor of ACE2 expression and found that vitamin D appeared to inhibit ACE2 expression in human bronchial smooth muscle cells by means of the VDR and other transcription factors. Of the 332 genes coding for the prey proteins of $S A R S-C o V-2$, vitamin $\mathrm{D}$ affects the expression of $84(25 \%)$. These prey proteins carry out a host of cellular functions which are disrupted by infection. This suggests that, in addition to inhibiting the expression of ACE-2, vitamin D is able to disrupt the function of 19 out of $27(70 \%)$ SARS$\mathrm{CoV}-2$ proteins [113]. While highly convincing, mechanistic studies confirming the role of vitamin D in SARS-CoV-2 infections using transcriptomic or metabolomic analyses are eagerly awaited. Nevertheless, several observational studies and randomised controlled or open-label trials have shown significant associations between vitamin D and COVID-19 (Table 1).

Table 1. Characteristics of studies examining the links between vitamin D and COVID-19*.

\begin{tabular}{|c|c|c|c|}
\hline $\begin{array}{l}\text { Author, Year, } \\
\text { Country [Ref] }\end{array}$ & Study Design & Sample Size & Main Findings \\
\hline $\begin{array}{l}\text { Whittemore et al., } \\
2020[114]\end{array}$ & $\begin{array}{l}\text { Correlation analysis } \\
\text { of data }\end{array}$ & 88 countries & $\begin{array}{l}\text { Countries closer to the equator had lower COVID-19 fatalities } \\
\text { than countries further away; } 16 \% \text { of this effect was attributed } \\
\text { to latitude. }\end{array}$ \\
\hline $\begin{array}{l}\text { Baktash et al., 2021, } \\
\text { UK [115] }\end{array}$ & Cohort study & 105 & $\begin{array}{l}\text { Vitamin D deficiency was associated with needing more care, } \\
\text { and with the occurrence of cytokine storms. }\end{array}$ \\
\hline $\begin{array}{l}\text { D'Avolio et al., } \\
\text { 2020, Switzerland } \\
{[116]}\end{array}$ & $\begin{array}{l}\text { Retrospective } \\
\text { cohort study }\end{array}$ & 107 & $\begin{array}{l}\text { People who tested positive for } S A R S-C o V-2 \text { had lower levels } \\
\text { of } 25(\mathrm{OH}) \mathrm{D} .\end{array}$ \\
\hline $\begin{array}{l}\text { Meltzer et al., 2020, } \\
\text { USA [117] }\end{array}$ & $\begin{array}{l}\text { Retrospective } \\
\text { cohort study }\end{array}$ & 4314 & $\begin{array}{l}\text { Deficient vitamin D status was linked to increased risk of } \\
\text { COVID-19. }\end{array}$ \\
\hline $\begin{array}{l}\text { Radujkovic et al., } \\
\text { 2020, Germany } \\
{[118]}\end{array}$ & Retrospective study & 185 & $\begin{array}{l}\text { Vitamin D deficiency was associated with a higher risk of } \\
\text { invasive mechanical ventilation or death. }\end{array}$ \\
\hline $\begin{array}{l}\text { Lakkireddy et al., } \\
\text { 2021, India [119] }\end{array}$ & $\begin{array}{l}\text { Randomised prospective } \\
\text { open-label study }\end{array}$ & 87 & $\begin{array}{l}\text { Vitamin D supplementation in those with hypovitaminosis D } \\
\text { improved inflammatory markers. }\end{array}$ \\
\hline $\begin{array}{l}\text { Ünsal et al., 2021, } \\
\text { Turkey [120] }\end{array}$ & $\begin{array}{l}\text { Retrospective } \\
\text { cohort study }\end{array}$ & 56 & $\begin{array}{c}\text { Vitamin D deficient COVID-19 patients had significantly } \\
\text { lower haemoglobin and lymphocyte counts and higher levels } \\
\text { of inflammatory markers. }\end{array}$ \\
\hline $\begin{array}{l}\text { Entrenas Castillo } \\
\text { et al., 2020, } \\
\text { Spain [121] }\end{array}$ & $\begin{array}{l}\text { Parallel pilot } \\
\text { randomized open-label } \\
\text { trial * }\end{array}$ & 76 & $\begin{array}{l}\text { High dose calcifediol reduced the severity of COVID-19 in } \\
\text { patients requiring ICU admission. }\end{array}$ \\
\hline $\begin{array}{l}\text { Murai et al., 2021, } \\
\text { Brazil [122] }\end{array}$ & $\begin{array}{l}\text { Multi-centre parallel } \\
\text { double-blind RCT }\end{array}$ & 240 & $\begin{array}{l}\text { Single high dose cholecalciferol did not reduce hospital stay, } \\
\text { mortality, admission to ICU or need for ventilation compared } \\
\text { with placebo. }\end{array}$ \\
\hline $\begin{array}{l}\text { Rastogi et al., 2020, } \\
\text { India [123] }\end{array}$ & $\mathrm{RCT}$ & 40 & $\begin{array}{l}\text { Compared with vitamin D deficient individuals, a greater } \\
\text { proportion of asymptomatic or mildly symptomatic patients } \\
\text { on high dose vitamin D reaching } 25(\mathrm{OH}) \mathrm{D}>50 \mathrm{ng} / \mathrm{ml} \\
\text { achieved a negative } S A R S-C o V-2 \mathrm{RNA} \text { at } \leq 21 \text { days. }\end{array}$ \\
\hline $\begin{array}{l}\text { Annweiler et al., } \\
\text { 2020, France [124] }\end{array}$ & Quasi-randomised trial & 66 & $\begin{array}{c}\text { Vitamin D supplementation just before or during COVID-19 } \\
\text { in an aged population reduced disease severity and } \\
\text { mortality rate. }\end{array}$ \\
\hline
\end{tabular}


Table 1. Cont.

\begin{tabular}{|c|c|c|c|}
\hline $\begin{array}{l}\text { Author, Year, } \\
\text { Country [Ref] }\end{array}$ & Study Design & Sample Size & Main Findings \\
\hline $\begin{array}{l}\text { Munshi et al., } \\
\text { 2021, [125] }\end{array}$ & $\begin{array}{l}\text { Systematic review and } \\
\text { meta-analysis }\end{array}$ & $\begin{array}{l}6 \text { retrospective } \\
\text { articles }\end{array}$ & $\begin{array}{l}\text { Vitamin D levels could be a useful prognostic indicator of } \\
\text { COVID-19 outcomes. }\end{array}$ \\
\hline $\begin{array}{l}\text { Stroehlein et al., } \\
2021 \text { [126] }\end{array}$ & $\begin{array}{l}\text { Living Cochrane } \\
\text { systematic review }\end{array}$ & 3 RCTs & $\begin{array}{l}\text { Current evidence is insufficient to conclusively determine the } \\
\text { benefits or harms of vitamin D supplementation as a } \\
\text { treatment for COVID-19. }\end{array}$ \\
\hline $\begin{array}{l}\text { Annweiler et al., } \\
\text { 2020, France [127] }\end{array}$ & $\begin{array}{l}\text { Open-label, multicenter, } \\
\text { superiority RCT }\end{array}$ & & $\begin{array}{l}\text { Single dose of 50,000 IU of vitamin D vs Single dose of } \\
\text { 200,000 IU of vitamin D in COVID-19 positive patients } \\
\text { showing at least one sign of increased risk.Results pending. }\end{array}$ \\
\hline $\begin{array}{l}\text { Annweiler et al., } \\
\text { 2020, France [128] }\end{array}$ & $\begin{array}{l}\text { Quasi-experimental } \\
\text { study }\end{array}$ & 77 & $\begin{array}{l}\text { Regular vitamin D supplementation prior to COVID-19 led to } \\
\text { improved mortality in elderly patients at three months } \\
\text { follow-up. }\end{array}$ \\
\hline $\begin{array}{l}\text { Pereira et al., } \\
2020 \text { [129] }\end{array}$ & $\begin{array}{l}\text { Systematic review and } \\
\text { meta-analysis }\end{array}$ & 21 studies & $\begin{array}{l}\text { Correlation between severely ill COVID-19 patients and low } \\
\text { vitamin D levels [130], possibly explained by } 25(\mathrm{OH}) \mathrm{D} \text { being } \\
\text { inversely associated with pro-inflammatory cytokines, such } \\
\text { as IL-6, increase in CRP, and cardiac insufficiency, which } \\
\text { relate to severity of COVID-19 and to its unfavorable } \\
\text { outcomes [131]. Despite the correlation between higher } \\
\text { vitamin D levels, immune defenses, and favorable prognoses } \\
\text { in other viral infections [132], no causal relationship has been } \\
\text { established between } 25(\mathrm{OH}) \mathrm{D} \text { deficiency and vulnerability to } \\
\text { infection by COVID-19, by testing and blood vitamin D test in } \\
\text { SARS-CoV-2 patients. }\end{array}$ \\
\hline
\end{tabular}

Patients were administered $1000 \mathrm{IU} / \mathrm{d}$ oral vitamin D3,

Tan et al., 2020,

Singapore [133]

Cohort Study

43

$150 \mathrm{mg} / \mathrm{d}$ oral magnesium, and $500 \mathrm{mcg} / \mathrm{d}$ oral vitamin B12 upon admission if they did not require oxygen therapy. After correcting for demographics and hypertension, patients who received DMB had significantly less deterioration to the point of requiring oxygen therapy or intensive care support.

Other than age and non-white race, vitamin D deficient status Meltzer et al., 2020， Retrospective cohort USA [134] study was correlated with the incidence of COVID-19. However, the dose of vitamin D supplementation was not significantly correlated with the likelihood of testing positive to COVID-19.

Kaufman et al., 2020, USA [135]

observational analysis

191,779

SARS-CoV-2 incidence was higher in the patients with deficient $25(\mathrm{OH}) \mathrm{D}$ scores than in patients with adequate values and those with levels $\geq 55 \mathrm{ng} / \mathrm{mL}$.

Mean vitamin D levels were significantly higher in asymptomatic patients than severely ill. Prevalence of vitamin

$\mathrm{D}$ deficiency was significantly higher in the severely ill. Of

Jain et al., 2020, India [136]

Observational study

154 patients, 90 were deficient in vitamin D (29 asymptomatic; 61 severely ill). Serum levels of inflammatory markers, inflammatory response and fatality rate were higher in vitamin D deficient patients (21\% vs 3.1\%). Vitamin D level was markedly low in severe COVID-19 patients.

After 10 days of hospitalization, patients with severe vitamin

D deficiency had a $50 \%$ mortality probability, while those

Carpagnano et al. 2020, Italy [137]
Retrospective observational study
42 with insufficiency or moderate deficiency had a $5 \%$ mortality risk. COVID-19 patients with acute respiratory failure treated in RICU were found to have a high prevalence of hypovitaminosis $\mathrm{D}$, which correlated with a high mortality risk. 
Table 1. Cont.

\begin{tabular}{|c|c|c|c|}
\hline $\begin{array}{l}\text { Author, Year, } \\
\text { Country [Ref] }\end{array}$ & Study Design & Sample Size & Main Findings \\
\hline $\begin{array}{l}\text { Padhi et al., 2020, } \\
\text { India [138] }\end{array}$ & Observational study & NA & $\begin{array}{c}\text { Mean vitamin } \mathrm{D} \text { levels reported in different states and } \\
\text { territories correlated inversely with mortality data collected } \\
\text { via government statistics. }\end{array}$ \\
\hline $\begin{array}{l}\text { Ling et al., 2020, } \\
\text { UK [139] }\end{array}$ & $\begin{array}{l}\text { Retrospective } \\
\text { observational study }\end{array}$ & 444 & $\begin{array}{c}\text { Administration of cholecalciferol booster was correlated with } \\
\text { a reduced risk of COVID-19 mortality }\end{array}$ \\
\hline $\begin{array}{l}\text { De Smet et al., } \\
\text { 2021, Belgium } \\
{[140]}\end{array}$ & $\begin{array}{l}\text { Retrospective } \\
\text { observational trial }\end{array}$ & 186 & $\begin{array}{l}\text { Vitamin D deficiency on admission was associated with } \\
\text { mortality, independently of age, chronic lung disease, and the } \\
\text { extent of lung damage seen from chest CT severity score. }\end{array}$ \\
\hline $\begin{array}{l}\text { Karahan et al., } \\
\text { 2021, Turkey [141] }\end{array}$ & $\begin{array}{l}\text { Retrospective } \\
\text { observational study }\end{array}$ & 149 & $\begin{array}{l}\text { Serum } 25(\mathrm{OH}) \mathrm{D} \text { deficiency was associated with increased } \\
\text { mortality in COVID-19 patients. }\end{array}$ \\
\hline $\begin{array}{l}\text { AlSafar et al., 2021, } \\
\text { UAE, [142] }\end{array}$ & $\begin{array}{l}\text { Retrospective } \\
\text { observational study }\end{array}$ & 464 & $\begin{array}{l}\text { After ruling out sex as a predictor for COVID-19 severity or } \\
\text { mortality, } 25(\mathrm{OH}) \mathrm{D} \text { levels below } 12 \mathrm{ng} / \mathrm{mL} \text { were significantly } \\
\text { correlated with increased risk of severe illness and mortality. }\end{array}$ \\
\hline $\begin{array}{l}\text { Orchard et al., } \\
\text { 2021, UK [143] }\end{array}$ & Cohort study & 646 & $\begin{array}{l}\text { No significant correlation reported between low vitamin D } \\
\text { levels and severity of COVID-19 or mortality. }\end{array}$ \\
\hline $\begin{array}{l}\text { Osman et al., 2021, } \\
\text { Oman [144] }\end{array}$ & $\begin{array}{l}\text { Observational } \\
\text { cohort study }\end{array}$ & 445 & $\begin{array}{c}\text { While no correlation between vitamin D and disease severity } \\
\text { and progression was observed, there was an association } \\
\text { between hypocalcaemia and COVID-19 severity. The } \\
\text { relationship between calcium and vitamin D is } \\
\text { also acknowledged. }\end{array}$ \\
\hline $\begin{array}{l}\text { Diaz-Curiel et al., } \\
\text { 2021, Spain [145] }\end{array}$ & $\begin{array}{l}\text { Retrospective } \\
\text { observational study }\end{array}$ & 1549 & $\begin{array}{l}\text { Vitamin D deficiency was correlated with an increased risk of } \\
\text { hospital admission and critical care, but not mortality. }\end{array}$ \\
\hline $\begin{array}{l}\text { Angelidi et al., } \\
\text { 2021, USA [146] }\end{array}$ & $\begin{array}{l}\text { Retrospective } \\
\text { cohort study }\end{array}$ & 144 & $\begin{array}{l}\text { Mortality in hospital and need for mechanical ventilation } \\
\text { were inversely correlated with serum vitamin D level }\end{array}$ \\
\hline $\begin{array}{l}\text { Jevalikar et al., } \\
\text { 2021, Indian [147] }\end{array}$ & $\begin{array}{l}\text { Prospective } \\
\text { observational study }\end{array}$ & 410 & $\begin{array}{l}\text { No association between vitamin D deficiency and incidence of } \\
\text { severe COVID-19, increased oxygen requirement, ICU } \\
\text { admissions or mortality. In vitamin D deficient patients who } \\
\text { received cholecalciferol treatment, there was no significant } \\
\text { improvement in outcome. }\end{array}$ \\
\hline $\begin{array}{l}\text { Alcala-Diaz et al., } \\
\text { 2021, Spain [148] }\end{array}$ & $\begin{array}{l}\text { Retrospective, } \\
\text { multicentre, } \\
\text { non-randomised } \\
\text { cohort study }\end{array}$ & 537 & $\begin{array}{l}\text { Calcifediol treatment after COVID-19 diagnosis was } \\
\text { significantly associated with reduced 30-day mortality }\end{array}$ \\
\hline $\begin{array}{l}\text { Cangiano et al., } \\
\text { 2020, Italy [149] }\end{array}$ & Observational study & 157 & $\begin{array}{l}\text { Mortality in COVID-19 patients was found to be inversely } \\
\text { associated with vitamin D supplementation }\end{array}$ \\
\hline $\begin{array}{l}\text { Fasano et al., 2020, } \\
\text { Italy [150] }\end{array}$ & Cohort study & 1486 & $\begin{array}{c}\text { Among Parkinson's Disease patients, COVID-19 incidence } \\
\text { was greater among those who were younger, obese and those } \\
\text { with COPD. It was less likely among patients who had } \\
\text { vitamin D supplementation. }\end{array}$ \\
\hline $\begin{array}{l}\text { Giannini et al., } \\
\text { 2021, Italy [151] }\end{array}$ & Retrospective study & 91 & $\begin{array}{l}\text { Two doses of 200,000 IU of vitamin D administered on } \\
\text { consecutive days can improve outcomes (ICU admission, } \\
\text { mortality) in patients with comorbidities. }\end{array}$ \\
\hline $\begin{array}{l}\text { Israel et al., 2021, } \\
\text { Israel [152] }\end{array}$ & Case-control study & 60,039 & $\begin{array}{l}\text { The only statins that exerted a protective effect in COVID-19 } \\
\text { were those that increased levels of } 25(\mathrm{OH}) \mathrm{D} \text {, such } \\
\text { as rosuvastatin. }\end{array}$ \\
\hline $\begin{array}{l}\text { Loucera et al., 2021, } \\
\text { Andalusia [153] }\end{array}$ & $\begin{array}{l}\text { Retrospective } \\
\text { survival study }\end{array}$ & 16,401 & $\begin{array}{c}\text { There was significant reduction in mortality after } \\
\text { administration of vitamin D (calcifediol) 15-30 days } \\
\text { before hospitalisation }\end{array}$ \\
\hline
\end{tabular}


Table 1. Cont.

\begin{tabular}{lccc}
\hline $\begin{array}{c}\text { Author, Year, } \\
\text { Country [Ref] }\end{array}$ & Study Design & Sample Size & Main Findings \\
\hline $\begin{array}{l}\text { Sabico et al., 2021, } \\
\text { Saudi Arabia [154] }\end{array}$ & RCT & 69 & $\begin{array}{c}5000 \text { IU, but not 1000 IU, daily administration of vitamin D } \\
\text { for 2 weeks reduced recovery time for COVID-19 patients } \\
\text { with mild to moderate symptoms. Both groups showed } \\
\text { decreases in levels of IL-6 and BMI over time. }\end{array}$ \\
\hline $\begin{array}{l}\text { Oristell et al., 2021, } \\
\text { Catalonia [155] }\end{array}$ & $\begin{array}{c}\text { Population based } \\
\text { cohort study }\end{array}$ & 108,343 & $\begin{array}{c}\text { Reduced serum 25(OH)D levels were associated with an } \\
\text { increased incidence of infection rather than disease severity or } \\
\text { mortality. Groups compared were supplemented vitamin D } \\
\text { sufficient versus non-supplemented vitamin D deficient } \\
\text { patients who contracted COVID-19 }\end{array}$ \\
\hline $\begin{array}{l}\text { Ohaegbulam et al., } \\
\text { 2020, USA [156] }\end{array}$ & Clinical case series & 4 & $\begin{array}{c}\text { Patients who received high dose supplementation in the form } \\
\text { of cholecalciferol or ergocalciferol had faster recovery, seen } \\
\text { from reduced inflammatory markers, comparative lower } \\
\text { oxygen requirements and reduced duration of hospital stay. }\end{array}$ \\
\hline $\begin{array}{l}\text { Nogues et al., 2021, } \\
\text { Spain [157] }\end{array}$ & Observational study & 838 & $\begin{array}{c}\text { In hospitalised COVID-19 patients, treatment with calcifediol } \\
\text { significantly reduced mortality and admission to ICU }\end{array}$ \\
\hline $\begin{array}{l}\text { Ma et al. 2021, } \\
\text { UK [158] }\end{array}$ & Prospective study & 8297 & $\begin{array}{c}\text { Habitual vitamin D supplementation was correlated with a } \\
\text { reduction in COVID-19 incidence. }\end{array}$ \\
\hline
\end{tabular}

Abbreviations: 25(OH)D, 25-hydroxyvitamin D; BMI, body mass index; COPD, chronic obstructive pulmonary disorder; COVID-19, coronavirus disease 2019; CRP, C-reactive protein; CT, computed tomography; DMB, combination of vitamin D3, magnesium and vitamin B12; ICU, intensive care unit; IL, interleukin; IU, international units; RCT, randomised controlled trial; RICU, respiratory intensive care unit; SARS-CoV-2, coronavirus severe acute respiratory syndrome. This list is representative of most observational and clinical studies conducted, not exhaustive. * open-label for hydroxychloroquine and azithromycin, double-blind for vitamin D.

\subsection{Observational Studies}

In the context of SARS-CoV-2 infections, there have been several observational studies investigating the role of vitamin D. A large cross-sectional study examining the geographical distribution of COVID-19 in the US drew links between sunlight exposure as a surrogate measure for vitamin D and outcomes such as disease severity and death from COVID19 [159]. Similarly, correlation analysis of data from 88 countries found that countries proximal to the equator had lower COVID-19 fatalities compared with distal countries, suggesting a potential link between vitamin D (by proxy of latitude and sunlight exposure) and COVID-19 fatality [114]. In a cohort study of an aging population, it was observed that COVID-19 patients admitted to a hospital in the UK had lower serum levels of vitamin D compared with healthy controls, and there was a noticeable correlation between vitamin $\mathrm{D}$ deficiency and needing increased care or ventilation [115]. Baktash et al. [115] also corroborated findings of vitamin D deficiency being associated with increased incidence of cytokine storms. Similarly, in two studies of 107 and 4314 patients in Switzerland and Chicago, those who tested positive for SARS-CoV-2 were more likely to have lower circulating 25(OH)D concentrations [116,117]. A retrospective study of 185 patients diagnosed with COVID-19 showed that those with low serum 25(OH)D levels were more likely to have poor outcomes, defined as the need for invasive mechanical ventilation or death [118]. Several studies have shown that receiving cholecalciferol or calcifediol treatment improves outcomes such as ICU admission and mortality $[139,149,151]$. Others have found associations between vitamin D sufficiency and reduced incidence of COVID-19, but not in outcomes after infection $[155,158]$. However, some studies have reported contrary, negative results $[143,144,147]$. Overall, the evidence supports the importance of the relationship between vitamin $\mathrm{D}$ and COVID-19, a relationship that requires continued investigation by means of large-scale, nationally representative studies.

\subsection{Clinical Trials}

A randomised prospective open-label study in India of 87 patients with COVID-19 and hypovitaminosis $D$ reported that supplementing vitamin $D$ in addition to standard care 
improved inflammatory markers significantly [119]. In the patients that received 60,000 IU of daily supplemental vitamin D for eight days, levels of C-reactive protein, lactase dehydrogenase, IL-6, ferritin, as well as neutrophil to lymphocyte ratios showed significant improvement compared to patients receiving no supplements. This was corroborated by a retrospective cohort study where COVID-19 patients with vitamin D deficiency had significantly lower haemoglobin and lymphocyte counts and higher levels of inflammatory markers, including C-reactive protein [120]. In addition, vitamin D deficient patients tended to require oxygen therapy and patients who had not corrected their vitamin $D$ levels six months prior to $S A R S-C o V-2$ infection were more likely to be diagnosed with pneumonia [120]. A randomised controlled trial (RCT) in Spain [121] investigated the effects of hydroxychloroquine and azithromycin in combination with oral calcifediol in the treatment of COVID-19. While hydroxychloroquine and azithromycin were administered according to standard of care treatment, they reported that sufficient vitamin D levels brought about by calcifediol supplementation was the most apparent factor in determining disease prognosis [121]. Rastogi et al. [123] performed a RCT in India and found that three times as many asymptomatic or mildly symptomatic patients receiving high dose vitamin D (60,000 IU of daily cholecalciferol for 7 days) reaching a therapeutic target of $25(\mathrm{OH}) \mathrm{D}>50 \mathrm{ng} / \mathrm{mL}$ could attain a negative $S A R S-C o V-2$ RNA by day 21, compared with vitamin D-deficient placebo recipients. Conversely, another RCT in Brazil reported that among 240 hospitalized patients with COVID-19, a single high dose of 200,000 IU of cholecalciferol did not reduce hospital length of stay or affect in-hospital mortality, admission to ICU or need for mechanical ventilation compared with placebo [122]. It should be noted that participants in this study received diverse concomitant medications and were given vitamin $\mathrm{D}$ after a relatively long time from symptom onset (mean 10.3 days). Hence, it is unclear whether the null findings may be due to this delay and whether preventive or early vitamin D supplementation may be useful in treating mild or moderate COVID-19. Indeed, in a quasi-randomised trial investigating the possible prevention of infection in 66 aged-care residents in France, it was reported that vitamin D supplementation during or just before COVID-19 was associated with less severe disease and lower mortality rate [124]. Simultaneously, it was also shown that regular vitamin D supplementation prior to infection led to better survival among elderly patients [128]. A randomized controlled trial also showed that daily administration for 2 weeks of $5000 \mathrm{IU}$ but not $1000 \mathrm{IU}$ was reduced recovery time in patients with mild to moderate symptoms [154]. This was also seen from their decreases in BMI and IL-6 levels over time. These studies support the potential for vitamin D supplementation to be used as an adjunct therapy to improve clinical outcomes in COVID-19 [125].

\section{Limitations and Future Directions}

The progress of the field is, to a great extent, limited by the rapidly evolving nature of the virus as well as its emerging effects on the immune system which are not yet fully understood. The phenomenon of more contagious or virulent strains of the virus causing adverse outcomes even in younger populations that are thought to be more immunologically resilient, calls for re-examination of what little is known. Current evidence, while overwhelmingly supporting the hypothesis implicating vitamin D, is not absolute, with some groups reporting no relationship between vitamin D and COVID-19 once other confounding factors are considered [160]. In addition, the root cause of the lack of vitamin D and by extension, the immune dysfunction seen in COVID-19, is still being debated. The notion that diabetes and obesity (both concomitant with vitamin $\mathrm{D}$ deficient states) result in the increased fatality from COVID-19, rather than lack of vitamin D itself, has also been proposed and provides a plausible explanation [161]. Others argue the "healthy user effect", where healthy people who eat and exercise well spend more time outdoors and thus have higher vitamin D levels. This supports the correlations between vitamin $\mathrm{D}$ deficiency and poor outcomes after COVID-19, but not causation. Across the clinical trials reviewed here, it is apparent that there is substantial clinical and methodological heterogeneity, mainly 
owing to the different supplementation regimens and outcomes, as well as varied vitamin D status of participants. Together, these discrepancies preclude definitive conclusions and highlight the need for well-designed, adequately powered trials to determine the role of vitamin D in COVID-19. As noted in a recent Cochrane review [126], there are currently 21 ongoing trials that may shed some light on this topic in the near future.

In addition, it is important to acknowledge data limitations in observational studies. There are numerous reasons for the conclusions drawn from analysis of the dataset not being representative, and thus not being applicable. These include insufficient power, having a sample that is not representative of the population, the potential for false positives or negatives, or even unique circumstances that were overlooked and not accounted for in the multivariate analysis.

While there has been no preference in the literature regarding whether vitamin D is obtained via UVB exposure or supplementally, it is important to consider seasonal changes in physiological vitamin D synthesis. As a fat-soluble steroid hormone, vitamin $\mathrm{D}$ can be stored in adipose reservoirs for weeks at a time [162]. Supplementation should therefore take the pharmacokinetics of vitamin D into account. It should also be noted that studies demonstrating positive effects of vitamin D supplementation recommend treatment to restore levels to normal [159], whereas supraphysiological concentrations are not recommended. There have also been recommendations to pre-emptively treat low vitamin $\mathrm{D}$ levels as it reduces the severity of disease after infection. This needs to be considered and discussed further in the context of other risk factors such as aging and age-related deterioration of health [163]. Overall, there remains a great deal of work needed to evaluate the immunological effects of the mutant strains of $S A R S-C o V-2$. Moreover, the mechanistic pathways underlying the cellular and molecular functions of vitamin D concentrations in the context of COVID-19 await further study.

\section{Conclusions}

In summary, current evidence supports the links between vitamin D and COVID-19 and the benefits of vitamin D supplementation for managing or treating this condition. Most of the literature reports improved COVID-19 prognosis and outcomes with sufficient vitamin D concentrations, with or without supplementation, with some reporting no significant differences based on vitamin D levels and/or no improvements following supplementation. Some even report a decreased incidence of infection as a result of prior supplementation. Future research should focus on establishing the mechanism/s for this link, as well as optimising treatment doses for maximum benefit to patients once infected. In the meantime, vitamin D deficiency should be corrected wherever possible since vitamin D supplementation is safe and the potential for toxicity is strongly outweighed by the potential benefits in relation to protection from COVID-19.

Author Contributions: Writing - original draft preparation, D.G; investigation, data curation, D.G. and S.A.; writing-review and editing, D.G., S.A. and A.M.; conceptualization, supervision, A.M. All authors have read and agreed to the published version of the manuscript.

Funding: This research received no external funding. A.M. is supported by a biomedical research fellowship provided by the National Health and Medical Research Council (NHMRC) of Australia.

Institutional Review Board Statement: Not applicable.

Informed Consent Statement: Not applicable.

Data Availability Statement: Not applicable.

Conflicts of Interest: The authors declare no conflict of interest.

\section{References}

1. He, F.; Deng, Y.; Li, W. Coronavirus disease 2019: What we know? J. Med. Virol. 2020, 92, 719-725. [CrossRef]

2. Park, Y.J.; Walls, A.C.; Wang, Z.; Sauer, M.M.; Li, W.; Tortorici, M.A.; Bosch, B.J.; DiMaio, F.; Veesler, D. Structures of MERS-CoV spike glycoprotein in complex with sialoside attachment receptors. Nat. Struct. Mol. Biol. 2019, 26, 1151-1157. [CrossRef] 
3. Zhang, B.; Zhou, X.; Qiu, Y.; Feng, F.; Feng, J.; Jia, Y.; Zhu, H.; Hu, K.; Liu, J.; Liu, Z. Clinical characteristics of 82 death cases with COVID-19. PLOS ONE 2020, 15, e0235458.

4. Heymann, D.L.; Shindo, N. COVID-19: What is next for public health? Lancet 2020, 395, 542-545. [CrossRef]

5. World Health Organisation, (WHO) Coronavirus (COVID-19) Dashboard. Available online: https://covid19.who.int/ (accessed on 13 July 2021).

6. Blomberg, B.; Mohn, K.G.-I.; Brokstad, K.A.; Zhou, F.; Linchausen, D.W.; Hansen, B.-A.; Lartey, S.; Onyango, T.B.; Kuwelker, K.; Sævik, M.; et al. Long COVID in a prospective cohort of home-isolated patients. Nat. Med. 2021, 27, 1607-1613. [CrossRef] [PubMed]

7. Datta, S.D.; Talwar, A.; Lee, J.T. A proposed framework and timeline of the spectrum of disease due to SARS-CoV-2 infection: Illness beyond acute infection and public health implications. JAMA 2020, 324, 2251-2252. [CrossRef]

8. Greenhalgh, T.; Knight, M.; Buxton, M.; Husain, L. Management of post-acute covid-19 in primary care. BMJ 2020, 370 , m3026. [CrossRef]

9. Nalbandian, A.; Sehgal, K.; Gupta, A.; Madhavan, M.V.; McGroder, C.; Stevens, J.S.; Cook, J.R.; Nordvig, A.S.; Shalev, D.; Sehrawat, T.S.; et al. Post-acute COVID-19 syndrome. Nat. Med. 2021, 27, 601-615. [CrossRef]

10. Lei, J.; Kusov, Y.; Hilgenfeld, R. Nsp3 of coronaviruses: Structures and functions of a large multi-domain protein. Antivir. Res 2018, 149, 58-74. [CrossRef]

11. Liu, J.; Liu, Y.; Xia, H.; Zou, J.; Weaver, S.C.; Swanson, K.A.; Cai, H.; Cutler, M.; Cooper, D.; Muik, A.; et al. BNT162b2-elicited neutralization of B.1.617 and other SARS-CoV-2 variants. Nature 2021, 596, 273-275. [CrossRef] [PubMed]

12. Leung, K.; Shum, M.H.; Leung, G.M.; Lam, T.T.; Wu, J.T. Early transmissibility assessment of the N501Y mutant strains of SARS-CoV-2 in the United Kingdom, October to November 2020. Eurosurveillance 2021, 26, 2002106. [CrossRef]

13. Davies, N.G.; Jarvis, C.I.; Edmunds, W.J.; Jewell, N.P.; Diaz-Ordaz, K.; Keogh, R.H. Increased mortality in community-tested cases of SARS-CoV-2 lineage B.1.1.7. Nature 2021, 593, 270-274. [CrossRef] [PubMed]

14. Hulswit, R.J.G.; Lang, Y.; Bakkers, M.J.G.; Li, W.; Li, Z.; Schouten, A.; Ophorst, B.; van Kuppeveld, F.J.M.; Boons, G.J.; Bosch, B.J.; et al. Human coronaviruses OC43 and HKU1 bind to 9-O-acetylated sialic acids via a conserved receptor-binding site in spike protein domain A. Proc. Natl. Acad. Sci. USA 2019, 116, 2681-2690. [CrossRef] [PubMed]

15. Hoffmann, M.; Kleine-Weber, H.; Schroeder, S.; Krüger, N.; Herrler, T.; Erichsen, S.; Schiergens, T.S.; Herrler, G.; Wu, N.H.; Nitsche, A.; et al. Sars-cov-2 cell entry depends on ace2 and tmprss 2 and is blocked by a clinically proven protease inhibitor. Cell 2020, 181, 271-280.e278. [CrossRef]

16. Letko, M.; Marzi, A.; Munster, V. Functional assessment of cell entry and receptor usage for SARS-CoV-2 and other lineage B betacoronaviruses. Nat. Microbiol. 2020, 5, 562-569. [CrossRef] [PubMed]

17. Wan, Y.; Shang, J.; Graham, R.; Baric, R.S.; Li, F. Receptor recognition by the novel coronavirus from Wuhan: An analysis based on decade-long structural studies of SARS coronavirus. J. Virol. 2020, 94, e00127-20. [CrossRef] [PubMed]

18. Abdelrahman, Z.; Li, M.; Wang, X. Comparative Review of SARS-CoV-2, SARS-CoV, MERS-CoV, and Influenza A Respiratory Viruses. Front. Immunol. 2020, 11. [CrossRef]

19. Dhama, K.; Khan, S.; Tiwari, R.; Sircar, S.; Bhat, S.; Malik, Y.S.; Singh, K.P.; Chaicumpa, W.; Bonilla-Aldana, D.K.; RodriguezMorales, A.J. Coronavirus disease 2019-COVID-19. Clin. Microbiol. Rev. 2020, 33, e00028-20. [CrossRef]

20. Li, X.; Geng, M.; Peng, Y.; Meng, L.; Lu, S. Molecular immune pathogenesis and diagnosis of COVID-19. J Pharm. Anal. 2020, 10, 102-108. [CrossRef] [PubMed]

21. Cui, J.; Li, F.; Shi, Z.-L. Origin and evolution of pathogenic coronaviruses. Nat. Rev. Microbiol. 2019, 17, 181-192. [CrossRef]

22. V'kovski, P.; Kratzel, A.; Steiner, S.; Stalder, H.; Thiel, V. Coronavirus biology and replication: Implications for SARS-CoV-2. Nat. Rev. Microbiol. 2021, 19, 155-170. [CrossRef]

23. Oliveira, T.L.; Melo, I.S.; Cardoso-Sousa, L.; Santos, I.A.; El Zoghbi, M.B.; Shimoura, C.G.; Georjutti, R.P.; Castro, O.W.; Goulart, L.R.; Jardim, A.C.G.; et al. Pathophysiology of SARS-CoV-2 in Lung of Diabetic Patients. Front. Physiol. 2020, 11. [CrossRef]

24. Kuba, K.; Imai, Y.; Rao, S.; Gao, H.; Guo, F.; Guan, B.; Huan, Y.; Yang, P.; Zhang, Y.; Deng, W.; et al. A crucial role of angiotensin converting enzyme 2 (ACE2) in SARS coronavirus-induced lung injury. Nat. Med. 2005, 11, 875-879. [CrossRef] [PubMed]

25. Li, Y.C.; Qiao, G.; Uskokovic, M.; Xiang, W.; Zheng, W.; Kong, J. Vitamin D: A negative endocrine regulator of the renin-angiotensin system and blood pressure. J. Steroid. Biochem. Mol. Biol. 2004, 89-90, 387-392. [CrossRef] [PubMed]

26. Imai, Y.; Kuba, K.; Rao, S.; Huan, Y.; Guo, F.; Guan, B.; Yang, P.; Sarao, R.; Wada, T.; Leong-Poi, H.; et al. Angiotensin-converting enzyme 2 protects from severe acute lung failure. Nature 2005, 436, 112-116. [CrossRef]

27. Nagase, T.; Uozumi, N.; Ishii, S.; Kume, K.; Izumi, T.; Ouchi, Y.; Shimizu, T. Acute lung injury by sepsis and acid aspiration: A key role for cytosolic phospholipase A2. Nat. Immunol. 2000, 1, 42-46. [CrossRef] [PubMed]

28. Ferrara, J.M.; Abhyankar, S.; Gilliland, D. Cytokine storm of graft-versus-host disease: A critical effector role for interleukin-1. In Proceedings of the Transplantation Proceedings, Paris, France, 16 August 1992; pp. 1216-1217.

29. Yuen, K.; Wong, S. Human infection by avian influenza A H5N1. Hong Kong Med. J. 2005, 11, 189-199.

30. Channappanavar, R.; Perlman, S. Pathogenic human coronavirus infections: Causes and consequences of cytokine storm and immunopathology. Semin. Immunopathol 2017, 39, 529-539. [CrossRef]

31. Herold, S.; Steinmueller, M.; Wulffen, W.V.; Cakarova, L.; Pinto, R.; Pleschka, S.; Mack, M.; Kuziel, W.A.; Corazza, N.; Brunner, T.; et al. Lung epithelial apoptosis in influenza virus pneumonia: The role of macrophage-expressed TNF-related apoptosis-inducing ligand. J. Exp. Med. 2008, 205, 3065-3077. [CrossRef] 
32. Ware, L.B.; Matthay, M.A. Alveolar fluid clearance is impaired in the majority of patients with acute lung injury and the acute respiratory distress syndrome. Am. J. Respir. Crit. Care Med. 2001, 163, 1376-1383. [CrossRef]

33. Yen, Y.T.; Liao, F.; Hsiao, C.H.; Kao, C.L.; Chen, Y.C.; Wu-Hsieh, B.A. Modeling the early events of severe acute respiratory syndrome coronavirus infection in vitro. J. Virol. 2006, 80, 2684-2693. [CrossRef]

34. Cheung, C.Y.; Poon, L.L.; Ng, I.H.; Luk, W.; Sia, S.F.; Wu, M.H.; Chan, K.H.; Yuen, K.Y.; Gordon, S.; Guan, Y.; et al. Cytokine responses in severe acute respiratory syndrome coronavirus-infected macrophages in vitro: Possible relevance to pathogenesis. $J$. Virol. 2005, 79, 7819-7826. [CrossRef]

35. Chien, J.Y.; Hsueh, P.R.; Cheng, W.C.; Yu, C.J.; Yang, P.C. Temporal changes in cytokine/chemokine profiles and pulmonary involvement in severe acute respiratory syndrome. Respirology 2006, 11, 715-722. [CrossRef]

36. Gu, J.; Gong, E.; Zhang, B.; Zheng, J.; Gao, Z.; Zhong, Y.; Zou, W.; Zhan, J.; Wang, S.; Xie, Z.; et al. Multiple organ infection and the pathogenesis of SARS. J. Exp. Med. 2005, 202, 415-424. [CrossRef] [PubMed]

37. Cui, W.; Fan, Y.; Wu, W.; Zhang, F.; Wang, J.Y.; Ni, A.P. Expression of lymphocytes and lymphocyte subsets in patients with severe acute respiratory syndrome. Clin. Infect. Dis. 2003, 37, 857-859. [CrossRef] [PubMed]

38. Xu, Z.; Shi, L.; Wang, Y.; Zhang, J.; Huang, L.; Zhang, C.; Liu, S.; Zhao, P.; Liu, H.; Zhu, L.; et al. Pathological findings of COVID-19 associated with acute respiratory distress syndrome. Lancet Respir. Med. 2020, 8, 420-422. [CrossRef]

39. Holick, M.F.; Chen, T.C. Vitamin D deficiency: A worldwide problem with health consequences. Am. J. Clin. Nutr. 2008, 87, 1080s-1086s. [CrossRef]

40. Horton-French, K.; Dunlop, E.; Lucas, R.M.; Pereira, G.; Black, L.J. Prevalence and predictors of vitamin D deficiency in a nationally representative sample of Australian adolescents and young adults. Eur. J. Clin. Nutr. 2021, 1-10. [CrossRef]

41. Amrein, K.; Scherkl, M.; Hoffmann, M.; Neuwersch-Sommeregger, S.; Köstenberger, M.; Tmava Berisha, A.; Martucci, G.; Pilz, S.; Malle, O. Vitamin D deficiency 2.0: An update on the current status worldwide. Eur. J. Clin. Nutr. 2020, 74, 1498-1513. [CrossRef]

42. Lamberg-Allardt, C. Vitamin D in foods and as supplements. Prog. Biophys. Mol. Biol. 2006, 92, 33-38. [CrossRef] [PubMed]

43. Zhang, J.; Habiel, D.M.; Ramadass, M.; Kew, R.R. Identification of two distinct cell binding sequences in the vitamin D binding protein. Biochim. Et Biophys. Acta (BBA)-Mol. Cell Res. 2010, 1803, 623-629. [CrossRef] [PubMed]

44. Cheng, J.B.; Levine, M.A.; Bell, N.H.; Mangelsdorf, D.J.; Russell, D.W. Genetic evidence that the human CYP2R1 enzyme is a key vitamin D 25-hydroxylase. Proc. Natl. Acad. Sci. 2004, 101, 7711-7715. [CrossRef] [PubMed]

45. Spitzer, V.; Höller, U. VITAMINS I Overview. In Encyclopedia of Analytical Science, 2nd ed.; Worsfold, P., Townshend, A., Poole, C., Eds.; Elsevier: Oxford, UK, 2005; pp. 147-159. [CrossRef]

46. Wöbke, T.K.; Sorg, B.L.; Steinhilber, D. Vitamin D in inflammatory diseases. Front. Physiol. 2014, 5. [CrossRef]

47. Gysemans, C.A.; Cardozo, A.K.; Callewaert, H.; Giulietti, A.; Hulshagen, L.; Bouillon, R.; Eizirik, D.L.; Mathieu, C. 1,25Dihydroxyvitamin D3 modulates expression of chemokines and cytokines in pancreatic islets: Implications for prevention of diabetes in nonobese diabetic mice. Endocrinology 2005, 146, 1956-1964. [CrossRef] [PubMed]

48. Takahashi, K.; Nakayama, Y.; Horiuchi, H.; Ohta, T.; Komoriya, K.; Ohmori, H.; Kamimura, T. Human neutrophils express messenger RNA of vitamin D receptor and respond to $1 \alpha$, 25-dihydroxyvitamin D3. Immunopharmacol. Immunotoxicol. 2002, 24, 335-347. [CrossRef]

49. Warwick, T.; Schulz, M.H.; Günther, S.; Gilsbach, R.; Neme, A.; Carlberg, C.; Brandes, R.P.; Seuter, S. A hierarchical regulatory network analysis of the vitamin D induced transcriptome reveals novel regulators and complete VDR dependency in monocytes. Sci. Rep. 2021, 11, 6518. [CrossRef]

50. Baeke, F.; Korf, H.; Overbergh, L.; van Etten, E.; Verstuyf, A.; Gysemans, C.; Mathieu, C. Human T lymphocytes are direct targets of 1,25-dihydroxyvitamin D3 in the immune system. J. Steroid Biochem. Mol. Biol. 2010, 121, 221-227. [CrossRef]

51. Provvedini, D.M.; Tsoukas, C.D.; Deftos, L.J.; Manolagas, S.C. 1, 25-dihydroxyvitamin D3 receptors in human leukocytes. Science 1983, 221, 1181-1183. [CrossRef]

52. Hewison, M.; Freeman, L.; Hughes, S.V.; Evans, K.N.; Bland, R.; Eliopoulos, A.G.; Kilby, M.D.; Moss, P.A.; Chakraverty, R. Differential regulation of vitamin D receptor and its ligand in human monocyte-derived dendritic cells. J. Immunol. 2003, 170, 5382-5390. [CrossRef]

53. Qayyum, S.; Mohammad, T.; Slominski, R.M.; Hassan, M.I.; Tuckey, R.C.; Raman, C.; Slominski, A.T. Vitamin D and lumisterol novel metabolites can inhibit Sars-cov-2 replication machinery enzymes. Am. J. Physiol. Endocrinol. Metab. 2021, 321, E246-E251. [CrossRef]

54. Khanal, R.C.; Nemere, I. The erp57/grp58/1,25d3-marrs receptor: Multiple functional roles in diverse cell systems. Curr. Med. Chem. 2007, 14, 1087-1093. [CrossRef]

55. Shirvani, A.; Kalajian, T.A.; Song, A.; Holick, M.F. Disassociation of vitamin d's calcemic activity and non-calcemic genomic activity and individual responsiveness: A randomized controlled double-blind clinical trial. Sci. Rep. 2019, 9, 17685. [CrossRef] [PubMed]

56. Slominski, A.T.; Li, W.; Kim, T.K.; Semak, I.; Wang, J.; Zjawiony, J.K.; Tuckey, R.C. Novel activities of cyp11a1 and their potential physiological significance. J. Steroid. Biochem. Mol. Biol. 2015, 151, 25-37. [CrossRef] [PubMed]

57. Slominski, A.T.; Chaiprasongsuk, A.; Janjetovic, Z.; Kim, T.K.; Stefan, J.; Slominski, R.M.; Hanumanthu, V.S.; Raman, C.; Qayyum, S.; Song, Y.; et al. Photoprotective properties of vitamin $\mathrm{d}$ and lumisterol hydroxyderivatives. Cell. Biochem. Biophys. 2020, 78 , 165-180. [CrossRef] [PubMed] 
58. Slominski, R.M.; Stefan, J.; Athar, M.; Holick, M.F.; Jetten, A.M.; Raman, C.; Slominski, A.T. Covid-19 and vitamin D: A lesson from the skin. Exp. Derm. 2020, 29, 885-890. [CrossRef]

59. Griffin, M.D.; Xing, N.; Kumar, R. Vitamin D and its analogs as regulators of immune activation and antigen presentation. Annu. Rev. Nutr. 2003, 23, 117-145. [CrossRef]

60. Colotta, F.; Jansson, B.; Bonelli, F. Modulation of inflammatory and immune responses by vitamin D. J. Autoimmun. 2017, 85, 78-97. [CrossRef]

61. Zhang, Y.; Leung, D.Y.; Richers, B.N.; Liu, Y.; Remigio, L.K.; Riches, D.W.; Goleva, E. Vitamin D inhibits monocyte/macrophage proinflammatory cytokine production by targeting MAPK phosphatase-1. J. Immunol. 2012, 188, 2127-2135. [CrossRef]

62. Chen, Y.; Liu, W.; Sun, T.; Huang, Y.; Wang, Y.; Deb, D.K.; Yoon, D.; Kong, J.; Thadhani, R.; Li, Y.C. 1,25-Dihydroxyvitamin D promotes negative feedback regulation of TLR signaling via targeting microRNA-155-SOCS1 in macrophages. J. Immunol. 2013, 190, 3687-3695. [CrossRef]

63. Liu, P.T.; Stenger, S.; Li, H.; Wenzel, L.; Tan, B.H.; Krutzik, S.R.; Ochoa, M.T.; Schauber, J.; Wu, K.; Meinken, C.; et al. Toll-like receptor triggering of a vitamin D-mediated human antimicrobial response. Science 2006, 311, 1770-1773. [CrossRef]

64. Carlberg, C. Vitamin D Signaling in the Context of Innate Immunity: Focus on Human Monocytes. Front. Immunol. 2019, 10, 2211. [CrossRef]

65. Ferreira, G.B.; Gysemans, C.A.; Demengeot, J.; Cunha, J.P.D.; Vanherwegen, A.S.; Overbergh, L.; Belle, T.L.V.; Pauwels, F.; Verstuyf, A.; Korf, H.; et al. 1,25-Dihydroxyvitamin D3 promotes tolerogenic dendritic cells with functional migratory properties in NOD mice. J. Immunol. 2014, 192, 4210-4220. [CrossRef] [PubMed]

66. Griffin, M.D.; Lutz, W.; Phan, V.A.; Bachman, L.A.; McKean, D.J.; Kumar, R. Dendritic cell modulation by 1alpha,25 dihydroxyvitamin D3 and its analogs: A vitamin D receptor-dependent pathway that promotes a persistent state of immaturity in vitro and in vivo. Proc. Natl. Acad. Sci. USA 2001, 98, 6800-6805. [CrossRef]

67. Wildenberg, M.E.; Helden-Meeuwsen, C.G.V.; Merwe, J.P.V.D.; Moreno, C.; Drexhage, H.A.; Versnel, M.A. Lack of CCR5 on dendritic cells promotes a proinflammatory environment in submandibular glands of the NOD mouse. J. Leukoc. Biol. 2008, 83, 1194-1200. [CrossRef] [PubMed]

68. Unger, W.W.; Laban, S.; Kleijwegt, F.S.; Slik, A.R.V.D.; Roep, B.O. Induction of Treg by monocyte-derived DC modulated by vitamin D3 or dexamethasone: Differential role for PD-L1. Eur. J. Immunol. 2009, 39, 3147-3159. [CrossRef] [PubMed]

69. Kleijwegt, F.S.; Laban, S.; Duinkerken, G.; Joosten, A.M.; Zaldumbide, A.; Nikolic, T.; Roep, B.O. Critical role for TNF in the induction of human antigen-specific regulatory T cells by tolerogenic dendritic cells. J. Immunol. 2010, 185, 1412-1418. [CrossRef]

70. Skrobot, A.; Demkow, U.; Wachowska, M. Immunomodulatory Role of Vitamin D: A Review. Adv. Exp. Med. Biol. 2018, 1108, 13-23. [CrossRef] [PubMed]

71. Subramanian, K.; Bergman, P.; Henriques-Normark, B. Vitamin D Promotes Pneumococcal Killing and Modulates Inflammatory Responses in Primary Human Neutrophils. J. Innate. Immun. 2017, 9, 375-386. [CrossRef]

72. Lee, G.Y.; Park, C.Y.; Cha, K.S.; Lee, S.E.; Pae, M.; Han, S.N. Differential effect of dietary vitamin D supplementation on natural killer cell activity in lean and obese mice. J. Nutr. Biochem. 2018, 55, 178-184. [CrossRef]

73. Martens, P.J.; Gysemans, C.; Verstuyf, A.; Mathieu, A.C. Vitamin D's Effect on Immune Function. Nutrients 2020, $12,1248$. [CrossRef]

74. Halteren, A.G.V.; Tysma, O.M.; Etten, E.V.; Mathieu, C.; Roep, B.O. 1alpha,25-dihydroxyvitamin D3 or analogue treated dendritic cells modulate human autoreactive T cells via the selective induction of apoptosis. J. Autoimmun. 2004, 23, 233-239. [CrossRef]

75. Baeke, F.; Etten, E.V.; Overbergh, L.; Mathieu, C. Vitamin D3 and the immune system: Maintaining the balance in health and disease. Nutr. Res. Rev. 2007, 20, 106-118. [CrossRef]

76. Takiishi, T.; Belle, T.V.; Gysemans, C.; Mathieu, C. Effects of vitamin D on antigen-specific and non-antigen-specific immune modulation: Relevance for type 1 diabetes. Pediatr. Diabetes 2013, 14, 81-89. [CrossRef] [PubMed]

77. Mahon, B.D.; Wittke, A.; Weaver, V.; Cantorna, M.T. The targets of vitamin D depend on the differentiation and activation status of CD4 positive T cells. J. Cell Biochem. 2003, 89, 922-932. [CrossRef] [PubMed]

78. Jeffery, L.E.; Burke, F.; Mura, M.; Zheng, Y.; Qureshi, O.S.; Hewison, M.; Walker, L.S.; Lammas, D.A.; Raza, K.; Sansom, D.M. 1,25-Dihydroxyvitamin D3 and IL-2 combine to inhibit T cell production of inflammatory cytokines and promote development of regulatory T cells expressing CTLA-4 and FoxP3. J. Immunol. 2009, 183, 5458-5467. [CrossRef]

79. Lemire, J.M.; Adams, J.S.; Sakai, R.; Jordan, S.C. 1 alpha,25-dihydroxyvitamin D3 suppresses proliferation and immunoglobulin production by normal human peripheral blood mononuclear cells. J. Clin. Investig. 1984, 74, 657-661. [CrossRef]

80. Chen, S.; Sims, G.P.; Chen, X.X.; Gu, Y.Y.; Chen, S.; Lipsky, P.E. Modulatory effects of 1,25-dihydroxyvitamin D3 on human B cell differentiation. J. Immunol. 2007, 179, 1634-1647. [CrossRef] [PubMed]

81. Drozdenko, G.; Scheel, T.; Heine, G.; Baumgrass, R.; Worm, M. Impaired T cell activation and cytokine production by calcitriolprimed human B cells. Clin. Exp. Immunol. 2014, 178, 364-372. [CrossRef]

82. Slominski, A.T.; Kim, T.-K.; Qayyum, S.; Song, Y.; Janjetovic, Z.; Oak, A.S.W.; Slominski, R.M.; Raman, C.; Stefan, J.; Mier-Aguilar, C.A.; et al. Vitamin D and lumisterol derivatives can act on liver $x$ receptors (lxrs). Sci. Rep. 2021, 11, 8002. [CrossRef] [PubMed]

83. Bensinger, S.J.; Bradley, M.N.; Joseph, S.B.; Zelcer, N.; Janssen, E.M.; Hausner, M.A.; Shih, R.; Parks, J.S.; Edwards, P.A.; Jamieson, B.D. Lxr signaling couples sterol metabolism to proliferation in the acquired immune response. Cell 2008, 134, 97-111. [CrossRef]

84. Giménez, V.M.M.; Sanz, R.L.; Marón, F.J.M.; Ferder, L.; Manucha, W. Vitamin D-RAAS Connection: An Integrative Standpoint into Cardiovascular and Neuroinflammatory Disorders. Curr. Protein. Pept. Sci. 2020, 21, 948-954. [CrossRef] 
85. Mahdavi, A.M. A brief review of interplay between vitamin D and angiotensin-converting enzyme 2: Implications for a potential treatment for COVID-19. Rev. Med. Virol. 2020, 30, e2119.

86. Xu, J.; Yang, J.; Chen, J.; Luo, Q.; Zhang, Q.; Zhang, H. Vitamin D alleviates lipopolysaccharide-induced acute lung injury via regulation of the renin-angiotensin system. Mol. Med. Rep. 2017, 16, 7432-7438. [CrossRef] [PubMed]

87. Ambrosino, I.; Barbagelata, E.; Ortona, E.; Ruggieri, A.; Massiah, G.; Giannico, O.V.; Politi, C.; Moretti, A.M. Gender differences in patients with COVID-19: A narrative review. Monaldi. Arch. Chest. Dis. 2020, 90. [CrossRef] [PubMed]

88. Peckham, H.; Gruijter, N.M.D.; Raine, C.; Radziszewska, A.; Ciurtin, C.; Wedderburn, L.R.; Rosser, E.C.; Deakin, C.T.; Webb, K. Sex-bias in COVID-19: A meta-analysis and review of sex differences in disease and immunity. SSRN 2020, 3572881. [CrossRef]

89. Ghosh, S.; Klein, R.S. Sex Drives Dimorphic Immune Responses to Viral Infections. J. Immunol. 2017, 198, 1782-1790. [CrossRef]

90. Cai, H. Sex difference and smoking predisposition in patients with COVID-19. Lancet Respir. Med. 2020, 8, e20. [CrossRef]

91. Chappell, M.C.; Marshall, A.C.; Alzayadneh, E.M.; Shaltout, H.A.; Diz, D.I. Update on the Angiotensin converting enzyme 2-Angiotensin (1-7)-MAS receptor axis: Fetal programing, sex differences, and intracellular pathways. Front. Endocrinol. 2014, 4, 201. [CrossRef]

92. Dalpiaz, P.L.; Lamas, A.Z.; Caliman, I.F.; Ribeiro, R.F.J; Abreu, G.R.; Moyses, M.R.; Andrade, T.U.; Gouvea, S.A.; Alves, M.F.; Carmona, A.K.; et al. Sex Hormones Promote Opposite Effects on ACE and ACE2 Activity, Hypertrophy and Cardiac Contractility in Spontaneously Hypertensive Rats. PLoS ONE 2015, 10, e0127515. [CrossRef]

93. Samidurai, A.; Das, A. Cardiovascular Complications Associated with COVID-19 and Potential Therapeutic Strategies. Int. J. Mol. Sci. 2020, 21, 6790. [CrossRef]

94. Richardson, S.; Hirsch, J.S.; Narasimhan, M.; Crawford, J.M.; McGinn, T.; Davidson, K.W.; Barnaby, D.P.; Becker, L.B.; Chelico, J.D.; Cohen, S.L.; et al. Presenting Characteristics, Comorbidities, and Outcomes Among 5700 Patients Hospitalized With COVID-19 in the New York City Area. JAMA 2020, 323, 2052-2059. [CrossRef] [PubMed]

95. Jin, J.M.; Bai, P.; He, W.; Wu, F.; Liu, X.F.; Han, D.M.; Liu, S.; Yang, J.K. Gender Differences in Patients With COVID-19: Focus on Severity and Mortality. Front. Public Health 2020, 8, 152. [CrossRef]

96. Stokes, E.K.; Zambrano, L.D.; Anderson, K.N.; Marder, E.P.; Raz, K.M.; El Burai Felix, S.; Tie, Y.; Fullerton, K.E. Coronavirus Disease 2019 Case Surveillance-United States, January 22-May 30, 2020. MMWR Morb. Mortal. Wkly. Rep. 2020, 69, 759-765. [CrossRef]

97. Wortham, J.M.; Lee, J.T.; Althomsons, S.; Latash, J.; Davidson, A.; Guerra, K.; Murray, K.; McGibbon, E.; Pichardo, C.; Toro, B.; et al. Characteristics of Persons Who Died with COVID-19-United States, February 12-May 18, 2020. MMWR Morb. Mortal. Wkly. Rep. 2020, 69, 923-929. [CrossRef] [PubMed]

98. Gebhard, C.; Regitz-Zagrosek, V.; Neuhauser, H.K.; Morgan, R.; Klein, S.L. Impact of sex and gender on COVID-19 outcomes in Europe. Biol. Sex Differ. 2020, 11, 29. [CrossRef]

99. Sanghera, D.K.; Sapkota, B.R.; Aston, C.E.; Blackett, P.R. Vitamin D Status, Gender Differences, and Cardiometabolic Health Disparities. Ann. Nutr. Metab. 2017, 70, 79-87. [CrossRef]

100. Muscogiuri, G.; Barrea, L.; Somma, C.D.; Laudisio, D.; Salzano, C.; Pugliese, G.; Alteriis, G.D.; Colao, A.; Savastano, S. Sex Differences of Vitamin D Status across BMI Classes: An Observational Prospective Cohort Study. Nutrients 2019, $11,3034$. [CrossRef] [PubMed]

101. Spanier, J.A.; Nashold, F.E.; Mayne, C.G.; Nelson, C.D.; Hayes, C.E. Vitamin D and estrogen synergy in Vdr-expressing CD4(+) T cells is essential to induce Helios(+)FoxP3(+) T cells and prevent autoimmune demyelinating disease. J. Neuroimmunol. 2015, 286, 48-58. [CrossRef]

102. Mukherjee, S.; Pahan, K. Is COVID-19 Gender-sensitive? J. Neuroimmune Pharmacol. 2021, 16, 38-47. [CrossRef]

103. Hewison, M. Vitamin D and immune function: Autocrine, paracrine or endocrine? Scand. J. Clin. Lab. Investig. 2012, 72, 92-102.

104. Hansdottir, S.; Monick, M.M.; Hinde, S.L.; Lovan, N.; Look, D.C.; Hunninghake, G.W. Respiratory epithelial cells convert inactive vitamin D to its active form: Potential effects on host defense. J. Immunol. 2008, 181, 7090-7099. [CrossRef]

105. Hansdottir, S.; Monick, M.M. Vitamin D effects on lung immunity and respiratory diseases. Vitam. Horm. 2011, 86, 217-237. [PubMed]

106. Zehnder, D.; Bland, R.; Williams, M.C.; McNinch, R.W.; Howie, A.J.; Stewart, P.M.; Hewison, M. Extrarenal expression of 25-hydroxyvitamin d(3)-1 alpha-hydroxylase. J. Clin. Endocrinol. Metab. 2001, 86, 888-894. [CrossRef] [PubMed]

107. Kho, A.T.; Sharma, S.; Qiu, W.; Gaedigk, R.; Klanderman, B.; Niu, S.; Anderson, C.; Leeder, J.S.; Weiss, S.T.; Tantisira, K.G. Vitamin D related genes in lung development and asthma pathogenesis. BMC Med. Genom. 2013, 6, 1-9. [CrossRef] [PubMed]

108. Berry, D.J.; Hesketh, K.; Power, C.; Hyppönen, E. Vitamin D status has a linear association with seasonal infections and lung function in British adults. Br. J. Nutr. 2011, 106, 1433-1440. [CrossRef] [PubMed]

109. Cannell, J.J.; Vieth, R.; Umhau, J.C.; Holick, M.F.; Grant, W.B.; Madronich, S.; Garland, C.F.; Giovannucci, E. Epidemic influenza and vitamin D. Epidemiol. Infect. 2006, 134, 1129-1140. [CrossRef]

110. Silberstein, M. COVID-19 and IL-6: Why vitamin D (probably) helps but tocilizumab might not. Eur. J. Pharmacol. 2021, 899, 174031. [CrossRef]

111. Song, Y.; Qayyum, S.; Greer, R.A.; Slominski, R.M.; Raman, C.; Slominski, A.T.; Song, Y. Vitamin D3 and its hydroxyderivatives as promising drugs against covid-19: A computational study. J. Biomol. Struct. Dyn. 2021, 1-17. [CrossRef]

112. Slominski, A.T.; Slominski, R.M.; Goepfert, P.A.; Kim, T.K.; Holick, M.F.; Jetten, A.M.; Raman, C. Reply to jakovac and to rocha et al.: Can vitamin D prevent or manage covid-19 illness? Am. J. Physiol. Endocrinol. Metab. 2020, 319, E455-E457. [CrossRef] 
113. Glinsky, G.V. Tripartite Combination of Candidate Pandemic Mitigation Agents: Vitamin D, Quercetin, and Estradiol Manifest Properties of Medicinal Agents for Targeted Mitigation of the COVID-19 Pandemic Defined by Genomics-Guided Tracing of SARS-CoV-2 Targets in Human Cells. Biomedicines 2020, 8, 129. [CrossRef]

114. Whittemore, P.B. COVID-19 fatalities, latitude, sunlight, and vitamin D. Am. J. Infect. Control. 2020, 48, 1042-1044. [CrossRef] [PubMed]

115. Baktash, V.; Hosack, T.; Patel, N.; Shah, S.; Kandiah, P.; Abbeele, K.V.D.; Mandal, A.K.J.; Missouris, C.G. Vitamin D status and outcomes for hospitalised older patients with COVID-19. Postgrad. Med. J. 2021, 97, 442-447. [CrossRef] [PubMed]

116. D'Avolio, A.; Avataneo, V.; Manca, A.; Cusato, J.; Nicolò, A.D.; Lucchini, R.; Keller, F.; Cantù, M. 25-Hydroxyvitamin D Concentrations Are Lower in Patients with Positive PCR for SARS-CoV-2. Nutrients 2020, 12, 1359. [CrossRef] [PubMed]

117. Meltzer, D.O.; Best, T.J.; Zhang, H.; Vokes, T.; Arora, V.; Solway, J. Association of Vitamin D Status and Other Clinical Characteristics With COVID-19 Test Results. JAMA Netw. Open 2020, 3, e2019722. [CrossRef] [PubMed]

118. Radujkovic, A.; Hippchen, T.; Tiwari-Heckler, S.; Dreher, S.; Boxberger, M.; Merle, U. Vitamin D Deficiency and Outcome of COVID-19 Patients. Nutrients 2020, 12, 2757. [CrossRef]

119. Lakkireddy, M.; Gadiga, S.G.; Malathi, R.D.; Karra, M.L.; Raju, I.S.S.V.P.M.; Ragini; Chinapaka, S.; Baba, K.S.S.S.; Kandakatla, M. Impact of daily high dose oral vitamin D therapy on the inflammatory markers in patients with COVID 19 disease. Sci. Rep. 2021, 11, 10641. [CrossRef] [PubMed]

120. Ünsal, Y.A.; Gül, Ö.Ö.; Cander, S.; Ersoy, C.; Aydemir, E.; Ateş, C.; Uzun, Z.; Armağan, E.; Ünsal, O.; Ertürk, E. Retrospective analysis of vitamin D status on inflammatory markers and course of the disease in patients with COVID-19 infection. J. Endocrinol. Investig. 2021. [CrossRef]

121. Castillo, M.E.; Costa, L.M.E.; Barrios, J.M.V.; Díaz, J.F.A.; Miranda, J.L.; Bouillon, R.; Gomez, J.M.Q. Effect of calcifediol treatment and best available therapy versus best available therapy on intensive care unit admission and mortality among patients hospitalized for COVID-19: A pilot randomized clinical study. J. Steroid Biochem. Mol. Biol. 2020, 203, 105751. [CrossRef]

122. Murai, I.H.; Fernandes, A.L.; Sales, L.P.; Pinto, A.J.; Goessler, K.F.; Duran, C.S.C.; Silva, C.B.R.; Franco, A.S.; Macedo, M.B.; Dalmolin, H.H.H.; et al. Effect of a Single High Dose of Vitamin D3 on Hospital Length of Stay in Patients With Moderate to Severe COVID-19: A Randomized Clinical Trial. JAMA 2021, 325, 1053-1060. [CrossRef]

123. Rastogi, A.; Bhansali, A.; Khare, N.; Suri, V.; Yaddanapudi, N.; Sachdeva, N.; Puri, G.D.; Malhotra, P. Short term, high-dose vitamin D supplementation for COVID-19 disease: A randomised, placebo-controlled, study (SHADE study). Postgrad. Med. J. 2020. [CrossRef]

124. Annweiler, C.; Hanotte, B.; l'Eprevier, C.G.D.; Sabatier, J.M.; Lafaie, L.; Célarier, T. Vitamin D and survival in COVID-19 patients: A quasi-experimental study. J. Steroid Biochem. Mol. Biol. 2020, 204, 105771. [CrossRef]

125. Munshi, R.; Hussein, M.H.; Toraih, E.A.; Elshazli, R.M.; Jardak, C.; Sultana, N.; Youssef, M.R.; Omar, M.; Attia, A.S.; Fawzy, M.S.; et al. Vitamin D insufficiency as a potential culprit in critical COVID-19 patients. J. Med. Virol. 2021, 93, 733-740. [CrossRef]

126. Stroehlein, J.K.; Wallqvist, J.; Iannizzi, C.; Mikolajewska, A.; Metzendorf, M.I.; Benstoem, C.; Meybohm, P.; Becker, M.; Skoetz, N.; Stegemann, M.; et al. Vitamin D supplementation for the treatment of COVID-19: A living systematic review. Cochrane Database Syst. Rev. 2021, 5, Cd015043. [CrossRef]

127. Annweiler, C.; Beaudenon, M.; Gautier, J.; Simon, R.; Dubée, V.; Gonsard, J.; Parot-Schinkel, E.; Aidoud, A.; Albaret, G.; Annweiler, C.; et al. COvid-19 and high-dose VITamin D supplementation TRIAL in high-risk older patients (COVIT-TRIAL): Study protocol for a randomized controlled trial. Trials 2020, 21, 1031. [CrossRef] [PubMed]

128. Annweiler, G.; Corvaisier, M.; Gautier, J.; Dubée, V.; Legrand, E.; Sacco, G.; Annweiler, C. Vitamin D Supplementation Associated to Better Survival in Hospitalized Frail Elderly COVID-19 Patients: The GERIA-COVID Quasi-Experimental Study. Nutrients 2020, 12, 3377. [CrossRef]

129. Pereira, M.; Damascena, A.D.; Azevedo, L.M.G.; Oliveira, T.D.A.; Santana, J.D.M. Vitamin D deficiency aggravates COVID-19: Systematic review and meta-analysis. Crit. Rev. Food Sci. Nutr. 2020, 1-9. [CrossRef] [PubMed]

130. Liu, Y.; Yan, L.M.; Wan, L.; Xiang, T.X.; Le, A.; Liu, J.M.; Peiris, M.; Poon, L.L.M.; Zhang, W. Viral dynamics in mild and severe cases of COVID-19. Lancet Infect. Dis. 2020, 20, 656-657. [CrossRef]

131. Alipio, M. Vitamin D supplementation could possibly improve clinical outcomes of patients infected with coronavirus-2019 (COVID-19). Available SSRN 2020, 3571484.

132. Chirumbolo, S.; Bjørklund, G.; Sboarina, A.; Vella, A. The Role of Vitamin D in the Immune System as a Pro-survival Molecule. Clin. Ther. 2017, 39, 894-916. [CrossRef]

133. Tan, C.W.; Ho, L.P.; Kalimuddin, S.; Cherng, B.P.Z.; Teh, Y.E.; Thien, S.Y.; Wong, H.M.; Tern, P.J.W.; Chandran, M.; Chay, J.W.M.; et al. Cohort study to evaluate the effect of vitamin $\mathrm{D}$, magnesium, and vitamin $\mathrm{B}(12)$ in combination on progression to severe outcomes in older patients with coronavirus (COVID-19). Nutrition 2020, 79, 111017. [CrossRef]

134. Meltzer, D.O.; Best, T.J.; Zhang, H.; Vokes, T.; Arora, V.; Solway, J. Association of Vitamin D Deficiency and Treatment with COVID-19 Incidence. MedRxiv 2020. [CrossRef]

135. Kaufman, H.W.; Niles, J.K.; Kroll, M.H.; Bi, C.; Holick, M.F. SARS-CoV-2 positivity rates associated with circulating 25hydroxyvitamin D levels. PLoS ONE 2020, 15, e0239252. [CrossRef]

136. Jain, A.; Chaurasia, R.; Sengar, N.S.; Singh, M.; Mahor, S.; Narain, S. Analysis of vitamin D level among asymptomatic and critically ill COVID-19 patients and its correlation with inflammatory markers. Sci. Rep. 2020, 10, 20191. [CrossRef] 
137. Carpagnano, G.E.; Lecce, V.D.; Quaranta, V.N.; Zito, A.; Buonamico, E.; Capozza, E.; Palumbo, A.; Gioia, G.D.; Valerio, V.N.; Resta, O. Vitamin D deficiency as a predictor of poor prognosis in patients with acute respiratory failure due to COVID-19. J. Endocrinol. Investig. 2021, 44, 765-771. [CrossRef] [PubMed]

138. Padhi, S.; Suvankar, S.; Panda, V.K.; Pati, A.; Panda, A.K. Lower levels of vitamin D are associated with SARS-CoV-2 infection and mortality in the Indian population: An observational study. Int. Immunopharmacol. 2020, 88, 107001. [CrossRef] [PubMed]

139. Ling, S.F.; Broad, E.; Murphy, R.; Pappachan, J.M.; Pardesi-Newton, S.; Kong, M.F.; Jude, E.B. High-Dose Cholecalciferol Booster Therapy is Associated with a Reduced Risk of Mortality in Patients with COVID-19: A Cross-Sectional Multi-Centre Observational Study. Nutrients 2020, 12, 3799. [CrossRef]

140. Smet, D.D.; Smet, K.D.; Herroelen, P.; Gryspeerdt, S.; Martens, G.A. Serum 25(OH)D Level on Hospital Admission Associated With COVID-19 Stage and Mortality. Am. J. Clin. Pathol. 2021, 155, 381-388. [CrossRef] [PubMed]

141. Karahan, S.; Katkat, F. Impact of Serum 25(OH) Vitamin D Level on Mortality in Patients with COVID-19 in Turkey. J. Nutr. Health Aging 2021, 25, 189-196. [CrossRef]

142. AlSafar, H.; Grant, W.B.; Hijazi, R.; Uddin, M.; Alkaabi, N.; Tay, G.; Mahboub, B.; Anouti, F.A. COVID-19 Disease Severity and Death in Relation to Vitamin D Status among SARS-CoV-2-Positive UAE Residents. Nutrients 2021, 13, 1714. [CrossRef] [PubMed]

143. Orchard, L.; Baldry, M.; Nasim-Mohi, M.; Monck, C.; Saeed, K.; Grocott, M.P.W.; Ahilanandan, D. Vitamin-D levels and intensive care unit outcomes of a cohort of critically ill COVID-19 patients. Clin. Chem. Lab. Med. 2021, 59, 1155-1163. [CrossRef]

144. Osman, W.; Fahdi, F.A.; Salmi, I.A.; Khalili, H.A.; Gokhale, A.; Khamis, F. Serum Calcium and Vitamin D levels: Correlation with severity of COVID-19 in hospitalized patients in Royal Hospital, Oman. Int. J. Infect. Dis. 2021, 107, 153-163. [CrossRef]

145. Diaz-Curiel, M.; Cabello, A.; Arboiro-Pinel, R.; Mansur, J.L.; Heili-Frades, S.; Mahillo-Fernandez, I.; Herrero-González, A.; Andrade-Poveda, M. The relationship between 25(OH) vitamin D levels and COVID-19 onset and disease course in Spanish patients. J. Steroid Biochem. Mol. Biol. 2021, 212, 105928. [CrossRef] [PubMed]

146. Angelidi, A.M.; Belanger, M.J.; Lorinsky, M.K.; Karamanis, D.; Chamorro-Pareja, N.; Ognibene, J.; Palaiodimos, L.; Mantzoros, C.S. Vitamin D Status Is Associated With In-Hospital Mortality and Mechanical Ventilation: A Cohort of COVID-19 Hospitalized Patients. Mayo. Clin. Proc. 2021, 96, 875-886. [CrossRef]

147. Jevalikar, G.; Mithal, A.; Singh, A.; Sharma, R.; Farooqui, K.J.; Mahendru, S.; Dewan, A.; Budhiraja, S. Lack of association of baseline 25-hydroxyvitamin D levels with disease severity and mortality in Indian patients hospitalized for COVID-19. Sci. Rep. 2021, 11, 6258. [CrossRef]

148. Alcala-Diaz, J.F.; Limia-Perez, L.; Gomez-Huelgas, R.; Martin-Escalante, M.D.; Cortes-Rodriguez, B.; Zambrana-Garcia, J.L.; Entrenas-Castillo, M.; Perez-Caballero, A.I.; López-Carmona, M.D.; Garcia-Alegria, J.; et al. Calcifediol Treatment and Hospital Mortality Due to COVID-19: A Cohort Study. Nutrients 2021, 13, 1760. [CrossRef]

149. Cangiano, B.; Fatti, L.M.; Danesi, L.; Gazzano, G.; Croci, M.; Vitale, G.; Gilardini, L.; Bonadonna, S.; Chiodini, I.; Caparello, C.F.; et al. Mortality in an Italian nursing home during COVID-19 pandemic: Correlation with gender, age, ADL, vitamin D supplementation, and limitations of the diagnostic tests. Aging 2020, 12, 24522-24534. [CrossRef]

150. Fasano, A.; Cereda, E.; Barichella, M.; Cassani, E.; Ferri, V.; Zecchinelli, A.L.; Pezzoli, G. COVID-19 in Parkinson's Disease Patients Living in Lombardy, Italy. Mov. Disord. 2020, 35, 1089-1093. [CrossRef] [PubMed]

151. Giannini, S.; Passeri, G.; Tripepi, G.; Sella, S.; Fusaro, M.; Arcidiacono, G.; Torres, M.O.; Michielin, A.; Prandini, T.; Baffa, V.; et al. Effectiveness of In-Hospital Cholecalciferol Use on Clinical Outcomes in Comorbid COVID-19 Patients: A Hypothesis-Generating Study. Nutrients 2021, 13, 219. [CrossRef]

152. Israel, A.; Schäffer, A.A.; Cicurel, A.; Cheng, K.; Sinha, S.; Schiff, E.; Feldhamer, I.; Tal, A.; Lavie, G.; Ruppin, E. Identification of drugs associated with reduced severity of COVID-19-a case-control study in a large population. eLife 2021, 10, e68165. [CrossRef] [PubMed]

153. Loucera, C.; Peña-Chilet, M.; Esteban-Medina, M.; Muñoyerro-Muñiz, D.; Villegas, R.; Lopez-Miranda, J.; Rodriguez-Baño, J.; Túnez, I.; Bouillon, R.; Dopazo, J.; et al. Real world evidence of calcifediol use and mortality rate of COVID-19 hospitalized in a large cohort of 16,401 Andalusian patients. MedRxiv 2021. [CrossRef]

154. Sabico, S.; Enani, M.A.; Sheshah, E.; Aljohani, N.J.; Aldisi, D.A.; Alotaibi, N.H.; Alshingetti, N.; Alomar, S.Y.; Alnaami, A.M.; Amer, O.E.; et al. Effects of a 2-Week 5000 IU versus 1000 IU Vitamin D3 Supplementation on Recovery of Symptoms in Patients with Mild to Moderate Covid-19: A Randomized Clinical Trial. Nutrients 2021, 13, 2170. [CrossRef] [PubMed]

155. Oristrell, J.; Oliva, J.C.; Casado, E.; Subirana, I.; Domínguez, D.; Toloba, A.; Balado, A.; Grau, M. Vitamin D supplementation and COVID-19 risk: A population-based, cohort study. J. Endocrinol. Investig. 2021, 1-13. [CrossRef]

156. Ohaegbulam, K.C.; Swalih, M.; Patel, P.; Smith, M.A.; Perrin, R. Vitamin D Supplementation in COVID-19 Patients: A Clinical Case Series. Am. J. Ther. 2020, 27, e485-e490. [CrossRef]

157. Nogues, X.; Ovejero, D.; Pineda-Moncusí, M.; Bouillon, R.; Arenas, D.; Pascual, J.; Ribes, A.; Guerri-Fernandez, R.; Villar-Garcia, J.; Rial, A.; et al. Calcifediol treatment and COVID-19-related outcomes. J. Clin. Endocrinol. Metab. 2021. [CrossRef]

158. Ma, H.; Zhou, T.; Heianza, Y.; Qi, L. Habitual use of vitamin D supplements and risk of coronavirus disease 2019 (COVID-19) infection: A prospective study in UK Biobank. Am. J. Clin. Nutr. 2021, 113, 1275-1281. [CrossRef]

159. Marik, P.E.; Kory, P.; Varon, J. Does vitamin D status impact mortality from SARS-CoV-2 infection? Med. Drug Discov. 2020, 6, 100041. [CrossRef] 
160. Hastie, C.E.; Mackay, D.F.; Ho, F.; Celis-Morales, C.A.; Katikireddi, S.V.; Niedzwiedz, C.L.; Jani, B.D.; Welsh, P.; Mair, F.S.; Gray, S.R.; et al. Vitamin D concentrations and COVID-19 infection in UK Biobank. Diabetes Metab. Syndr. Clin. Res. Rev. 2020, 14, 561-565. [CrossRef] [PubMed]

161. Weir, E.K.; Thenappan, T.; Bhargava, M.; Chen, Y. Does vitamin D deficiency increase the severity of COVID-19? Clin. Med. 2020, 20, e107-e108. [CrossRef]

162. Mousa, A.; Naderpoor, N.; Courten, M.P.J.D.; Scragg, R.; Courten, B.D. 25-hydroxyvitamin D is associated with adiposity and cardiometabolic risk factors in a predominantly vitamin D-deficient and overweight/obese but otherwise healthy cohort. $J$. Steroid Biochem. Mol. Biol. 2017, 173, 258-264. [CrossRef]

163. Ilie, P.C.; Stefanescu, S.; Smith, L. The role of vitamin D in the prevention of coronavirus disease 2019 infection and mortality. Aging Clin. Exp. Res. 2020, 32, 1195-1198. [CrossRef] [PubMed] 